\title{
Climate Change, Adaptation Planning and Institutional Integration: A Literature Review and Framework
}

\author{
Nate Kauffman * and Kristina Hill *(D) \\ College of Environmental Design, University of California, Berkeley, CA 94720, USA \\ * Correspondence: natekauffman@berkeley.edu (N.K.); kzhill@berkeley.edu (K.H.)
}

Citation: Kauffman, N.; Hill, K. Climate Change, Adaptation Planning and Institutional Integration: A Literature Review and Framework. Sustainability 2021, 13, 10708. https://doi.org/10.3390/ su131910708

Academic Editor: Baojie He

Received: 1 August 2021

Accepted: 23 September 2021

Published: 27 September 2021

Publisher's Note: MDPI stays neutral with regard to jurisdictional claims in published maps and institutional affiliations.

Copyright: (c) 2021 by the authors. Licensee MDPI, Basel, Switzerland. This article is an open access article distributed under the terms and conditions of the Creative Commons Attribution (CC BY) license (https:/ / creativecommons.org/licenses/by/ $4.0 /)$.

\begin{abstract}
The scale and scope of climate change has triggered widespread acknowledgement of the need to adapt to it. Out of recent work attempting to understand, define, and contribute to the family of concepts related to adaptation efforts, considerable contributions and research have emerged. Yet, the field of climate adaptation constantly grapples with complex ideas whose relational interplay is not always clear. Similarly, understanding how applied climate change adaptation efforts unfold through planning processes that are embedded in broader institutional settings can be difficult to apprehend. We present a review of important theory, themes, and terms evident in the literature of spatial planning and climate change adaptation to integrate them and synthesize a conceptual framework illustrating their dynamic interplay. This leads to consideration of how institutions, urban governance, and the practice of planning are involved, and evolving, in shaping climate adaptation efforts. While examining the practice of adaptation planning is useful in framing how core climate change concepts are related, the role of institutional processes in shaping and defining these concepts-and adaptation planning itself-remains complex. Our framework presents a useful tool for approaching and improving an understanding of the interactive relationships of central climate change adaptation concepts, with implications for future work focused on change within the domains of planning and institutions addressing challenges in the climate change era.
\end{abstract}

Keywords: climate change; climate change adaptation; spatial planning; institutions; sustainability; resilience; uncertainty; vulnerability; adaptive capacity; urban governance

\section{Introduction}

The environmental severity and enormity of climate change is coming into sharper focus, as are considerations of crucial and complex impacts on society and daunting demands of the requisite efforts to adapt to it [1]. Climate Change Adaptation (CCA) is understood as a challenge ensnaring numerous actors across multiple societal sectors, acting as a nexus of overlapping concerns and connections [2]. Significant increases in literature concerned with climate change adaptation is evident, with commensurate scholarship dedicated to exploring key concepts in the field [3-5]. Hurdles to effectively engaging with climate adaptation concepts run the gamut: from the inaccessibility of scientific "jargon" [6] to the need to synthesize research and identify areas lacking attention $[7,8]$. Disentangling the roles and relationships between modes of preparing adaptive responses to climate change (planning) and the social patterns that govern these practices (institutions) reveal more areas of confusion and needed consideration, especially for examining how these practices and patterns may themselves adapt or be adapted $[4,9,10]$. While conceptual frameworks used to streamline and simplify complex ideas are common, frameworks constructed for the purpose of clarifying key concepts in the field of climate change adaptation planning are lacking.

Planning is a concept with wide and diverse meaning across numerous scales and disciplines [11]. While climate impacts on the atmosphere and oceans of earth are increasingly severe (and entail their own planning considerations), we are concerned here with 
spatial planning, which frames the landscape as a crucial, dynamic medium-a geographic template-upon and within which effects of climate change will be experienced most acutely by humans [12]. Spatial planning uses diverse scientific methods and information to shape decisions about how features of the landscape are designed, constructed, and managed. Berkes and Folke [13] sought to formalize the concept of social-ecological systems (SES) as linked human and natural systems that somehow "fit" together [14]; and a framework for "match[ing] the dynamics of institutions with the dynamics of ecosystems for mutual social-ecological resilience and improved performance." While earlier work on the concept was undertaken by Ratzlaff (1970) and later Cherkasskii (1988) reflects that the SES initialization is also used to denote 'socio-ecological' or 'socioecological' systems, Berkes and Folke sought to avoid a modifier (socio-) that would imply a subordinate role of the social features of SES (Colding, 2019). Nonetheless, they remain largely interchangeable in the literature. The concept's presence in publications across numerous subject areas has exploded in the 21st century [15], perhaps reflecting or coinciding with increasing interest in the climate crisis and the human role and responses to it. SESs are useful here as a way of examining human interactions with and within the geographic template, and determining how technical and scientific knowledge about SESs are used to inform action in order to shape it and its future states: the essence of spatial planning [16,17]. Planning decisions about shaping SESs are implicitly ethical because they may generate opportunities and challenges for future generations [18].

Because climate change is characterized by significant and potentially increasing uncertainty, decision-making processes are encountering complexity in planning adaptation efforts to address these "(super)wicked" problems [9,19-22]. This is especially true in urban regions complicated by the concentration, entanglement, exposure, and diversity of citizens, resources, assets, and the systems for their management evident there, as well as the numerous, multileveled and/or polycentric governance structures employed as administrative actors $[23,24]$. Urban areas are complex geographies, where deep and complicated histories, cultures, and institutions generate important questions about the social aspects of power, resources, and environmental health, safety, and justice [25,26]. For these reasons, while we do not rigorously analyze or compare issues arising from various scales of consideration that spatial planning constantly confronts (local vs. national; site-based vs. regional), we examine central ideas and themes related to CCA that are especially evident in densely populated, developed areas. Extensive research on the role and function of multi-level governance (MLG) is evident in CCA circles, as are discussions of various traditions, processes, and planning cultures across nations and regions of the globe (including recent work by Ishtiaque (2021) and DiGreggorio (2019) useful for deeper examination of multilevel governance dynamics.) Most of the discussion within this article is derived from-and applies most directly to-developed nations and western planning traditions whose similarities and features lend toward the generalization and synthesis useful in the construction of the proposed framework.

Meadows' [27,28] landmark 1972 study, Limits to Growth, was recently assessed to examine the "fit" between projections of troubling development trends modeled a halfcentury ago - and their potential implications for countless (and planetary) SESs. Specifically, the "Business as Usual" description of a scenario describing unsustainable development practices (in this instance, particularly as a function of pollution increases including atmospheric greenhouse gas concentrations) appears to be playing out today, potentially portending calamitous impacts for society by or before midcentury [29]. Given that countless planning endeavors have unfolded for decades within the context of a finite planet articulated by Limits to Growth, major questions emerge about what planning is fundamentally for, how it functions (or can fail), and how it is positioned to operate in the climate change era.

Moreover, insofar as planning is understood as a practice utilized for governing the use of resources and space, the institutions - rules, norms, customs, and conventions-that simultaneously overarch and undergird planning are crucial to consider, and perhaps the 
fundamental relationship between planning and institutions most of all [30]. This frames the basic question at the center of this review: how is climate change driving transformation of the human systems that must confront it? What are the prominent and salient concepts that characterize this confrontation, and how are they related-to one another and to the planning and institutional domains grappling with climate change? This literature review draws upon important concepts and themes from these fields and areas of interest, as well as synthesizes and integrates prominent concepts into a broadly applicable framework to further research and consideration of the relationships between these fields and ideas. We demonstrate that core concerns stemming from climate change studies are commonplace and of increasing relevance in planning and institutional domains, and that logical links between them can be articulated to illustrate relationships framing notable conceptual and thematic intersections and interactions; these, in turn, work to clarify areas of emphasis, key linkages, and important "blind spots" that persist in CCA research.

This article is structured as follows: Section 2 describes the review approach, and briefly situates spatial planning within a historical and theoretical context that frames consideration of important concepts in the climate adaptation literature. Section 3 integrates these into a Climate Change Adaptation Planning (CCAP) schema, and we describe its key phases. Section 4 examines how, in turn, the practice of adaptation planning is related to theory about adaptation features of interest. Synthesis and integration of these features produces a conceptual framework that exhibits the 'nested' and covalent relationships and dynamics therein, which is followed by an examination of the role of institutions in these dynamics. We close with a brief discussion and conclusion examining insights and further questions framed by the work.

\section{Climate Change Adaptation Planning: Prologue, Practice, Paradigm}

Our research is focused around a literature review that examines prominent themes related across several domains of interest to CCA: spatial planning, climate change, and institutions. Comparing ideas and terminology of importance across diverse fields and phenomena involving various sociocultural dynamics is complex for a variety of reasons [31]. This is especially true when theories of change in social patterns are involved because framing and contextualizing historical trends inevitably entails consideration of broad themes [32]. Our review considered highly-cited articles in the domains of interest to assemble a network of conceptual and empirical articles and studies engaging concepts with broad prominence in CCA research. This formed the basis of an approach articulated by Paré, as geared towards "identifying, describing, and transforming [important] concepts, constructs and relationships ... [to build a] higher order of theoretical structure" [33]. In turn, this approach was used as a theoretical and narrative basis for constructing a conceptual framework. This is a common goal and outcome of research linking interdisciplinary bodies of knowledge to explore associated phenomena by articulating "key factors, constructs, or variables" to describe logical relationships among them that correspond to the main tenets of the research [34,35]. Accompanying the narrative review, the framework is used to consider relevant issues in the institutional domain, as well as for framing a discussion about persistent challenges, emergent insights, and potential applications.

\subsection{A Very Brief History of Modern Spatial Planning}

Landscape architecture arose as a formal design discipline in the 19th century based partially on the increasing recognition of connections between environmental and social health, out of which the sub-discipline of landscape planning emerged [36]. Landscape design and planning's interests in large-scale (watershed, regional) geographies and dynamic environmental and human (system, network) processes led to a broader rationale for incorporating ecological considerations into multi-scalar spatial planning [12]. In the postwar era, ecological planning entered common parlance, further shaped by the concerns of the modern environmental movement's discontent with harmful effects of unbridled development $[37,38]$. One of the overarching themes in ecological views of spatial planning 
is the concept of the suitability of landscapes: how their inherent and potential qualities predispose them to various uses by humans [12].

Modern perspectives focusing on Sustainable Development (SD) emerged in the late 20th century largely to address the obvious tensions between intensifying resource management practices and future prosperity [28]. Goals to achieve SD have become key concerns in the climate change era, especially in urban areas of high development intensity $[39,40]$. The means by which these goals are achieved-the "pathways" taken to reach them-inherently entail strategic planning approaches because limited resources force choices that entail tradeoffs $[19,41-43]$. The scope and scale of climate change is coming into sharper focus in the 21st century, as are its implications for significant change and uncertainty over time $[20,22,44,45]$.

The failure of society to curb GHG emissions through climate mitigation has increased the need for climate adaptation, emerging as a central concern of spatial planners across the globe; with some anticipating a paradigm shift in the fields of spatial planning concerned with adaptation to more effectively address it [46-48]. Challenges especially evident for spatial planning in the climate era emerge when administrative units delineated in space (as municipal boundaries, borders, zones, etc.) do not adequately address or 'fit' well with the climate phenomena that defy socio-politically conceived and articulated 'lines on the (proverbial) map' $[49,50]$. Indeed, as the landscape itself is modified by climate change, increased flexibility will surely be required of the very planning processes meant to effectively manage it.

\subsection{Climate Change Adaptation: Central Concepts}

To situate the practice of spatial planning within CCA efforts and the diversity of interactions that SESs in the climate change era will confront, we summarize several core concepts important in climate adaptation work. These ideas serve to populate our conceptual framework in the next section, which, in turn, displays their relational and dynamic qualities within an integrated theoretical construct.

\subsubsection{Sustainability}

The harvesting, commodification, distribution, (re)uses, and disposal of resources is a ubiquitous human activity [51]. This is especially true in (and for the provision of) urban areas, where intense turnover and concentration of stocks occurs, recognition of which has given rise to studies of urban ecology and metabolism [52-55]. These processes also entail significant energy "footprints", and numerous environmental impacts, including pollution, result from them [56]. The concept of sustainability may be understood to mean the maintenance of some (economic, social, environmental) entity, process, and/or outcome over time, framed in the environmental context of SESs $[13,57,58]$. Thus, while resource management remains a central consideration of sustainability in general (and SD specifically), it is also understood as a concept with applications in broader social realms [14].

Resource scarcity (and competition) resulting from unsustainable management practices carries equity implications, both across extant socioeconomic classes and for future generations who may be disadvantaged or disenfranchised by prior resource usage [59-61] Because planning is a core component of development, $\mathrm{SD}$ is frequently invoked as a concept to guide both the means and ends of planning-for-sustainability, a topic of increasing importance in an era of rising environmental concern, uncertainty, and flux [62-64]. Some authors have argued that SES are the logical analytical unit for SD research, with others asserting that they contain inherently interrelated concepts with special relevance to adaptation, or the quality of adaptability $[16,65]$.

\subsubsection{Adaptation and Adaptive Capacity}

Influential scholarship concerning fundamentals about adaptation is extensive. For the purposes of CCA, it entails altering or adjusting systems and behavior to "alleviate 
adverse impacts of change or take advantage of new opportunities" through anticipation or response to climate change impacts [66]. Adaptation can be differentiated based on who is involved in adjustment, what prompts this adjustment, and how it is undertaken $[67,68]$. Together, they "manifest" adaptive capacity, through a variety of institutional and social mechanisms (Ibid.). While non-human (eco)systems may also be said to display CCA behavior (and possess adaptive capacity), we are concerned primarily with the active inception and application of human efforts to "influence the direction of change" in SESs affected by climate change [69-71]. Pelling [72] articulates transformation of SESs as a pathway along which adaptation may play out, arguing that adaptation may trigger fundamental changes that decouple systems from more linear modes of progression.

Efforts to manifest adaptive capacity may "backfire", potentially increasing vulnerability [73]. This is known as maladaptation [74,75]. Maladaptive outcomes bear the double burden of generally worsening conditions (reducing resilience or increasing vulnerability) at the implied mutual exclusion of building adaptive capacity due to resource limits [76]. While noting various viewpoints and definitions, Gallopín [77] describes adaptive capacity in SES generally as the capability to cope with environmental change combined with the ability to improve in relation to it. Eakin [78] argues that there are generic (developmentfocused) and specific (climate impact-focused) domains of adaptive capacity, and that pursuit of one may exclude, subordinate, or otherwise reduce the other. Whereas adaptation actions might be understood in intuitive ways as relating to adaptive capacity (a quality), these interact in the context of additional qualities-namely vulnerability and resilience-which define SESs in important ways.

\subsubsection{Vulnerability and Risk}

Vulnerability concerns adverse impacts that occur due to a state's "susceptibility to harm" resulting from potentially complex interplays of exposure and sensitivity to stresses; and it is amplified by a lack of adaptive capacity $[68,79,80]$. When harmful, these stresses take the form of hazards representing threats to systems, events that "realize" hazards in significant ways by causing damage are disasters, and those stemming from or involving natural phenomena are natural disasters [65,81-83]. Risk essentially describes the condition and degree(s) of being vulnerable (based on exposure, sensitivity, and capacity) to hazards [84]; and risks shape and define adaptive capacity itself [85]. Risks are generally thought to be, in some sense, quantifiable, i.e., capable of being rendered in terms of probabilities describing the likelihood of outcomes [86-89]. The concentration of people, resources, and systems in urban spaces implies increased exposure, and additional risk based on the location of urban assets (in coastal areas, for example) may arise [26,41]. Risk operates in and across various societal domains: it should be considered in social and economic terms in addition to physical ones, including their interactions [90].

\subsubsection{Resilience and Robustness}

Systems exposed to risk and experiencing vulnerability may cope with it by drawing upon internal resources, whose realization may reduce impacts. Since Holling's [91] pioneering work in studying ecosystems' capacity to withstand and rebound from states of disturbance,- to "absorb" and "persist" - resilience has become something of a darling within adaptation circles; prompting some to caution that its over-invocation might dilute its meaning [92]. Resilience is of particular importance in the context of climate change because it represents a desirable quality of interacting designed and natural systems, and their relationship to risk and vulnerability $[93,94]$.

Systems that are resilient possess features, including flexibility and diversity, redundancy and modularity, and safe failure characteristics [43]. These work to reduce risk from disasters, which manifests in various types that include interacting, interconnected, compound, and cascading risks [84]. The UN's [95] adoption of frameworks for identifying and evaluating these risks speaks to the centrality of disaster risk reduction (DRR) in adaptation and resilience concerns and approaches. If resilience is seen as flexibility in the 
face of disturbance, robustness might be understood as the capability to resist and withstand it [16]. According to this view, resilient and/or robust systems maintain their core structure despite disturbance, enough so as to avoid becoming vulnerable to the point of significant structural deformation or collapse [96].

\subsubsection{Uncertainty}

Planning is a process of anticipating, preparing for, and influencing future states of affairs. Uncertainty is a critically important epistemic situation that is inherent to planning because these 'affairs' of future states are influenced by numerous processes that engender and shape events, eventualities, and exigencies [21,97]. This is the meta-context of planning: the temporal dimension within which all socioecological systems play out. Uncertainty intrinsically implies what is unknown and/or unknowable [98]. It is a matter of degree; hence, "levels" of uncertainty exist [99]. Uncertainty is generally understood to increase as more distant futures are considered; and uncertainty may reflect, or be considered as a function of, complexity $[88,100]$.

As planning is intended to inform decision-making, it must ultimately confront uncertainty in that context, influencing the selection of options for coping with or managing it in acceptable ways [101-104]. In this sense, uncertainty actually produces the need to make decisions [105]. These decisions address, but can also produceI, uncertainty; environmental uncertainty (uncertainty for planning) and process uncertainty (uncertainty from planning) may also exist, emerge, and interact [88,106]. Christensen's [102] elegant rendering of planning problems hinges on two related processes and their relationship with uncertainty: identifying what to do (a goal) and determining how to do it (through technology), effectively invoking the "ends and means" dyad familiar across all disciplines of planning. The capacity to learn new information that changes how uncertainty is characterized (and, therefore, changes degrees of belief) is a fundamentally adaptive ability [107].

The sheer scale and scope of potential impacts that CCA seeks to address entail significant uncertainty about how and when they will play out, thus shaping the 'menu of options' for responding to them $[100,108,109]$. Uncertainty might be epistemic (stemming from a lack of knowledge), aleatory (due to intrinsic stochasticity), or both, and it can produce delays in decision-making [104]. A striking example of how the very conceptualization of uncertainty is evolving in the climate change era concerns the asserted "death" of stationarity [110]. Stationarity refers to the statistical concept that environmental fluctuations are bounded inside a value range that is stable (or stationary) over meaningfully long time scales, an assumption that undergirds countless modeling approaches in environmental science and engineering $[111,112]$. Whether or not reports of stationarity's death have been greatly exaggerated, uncertainty is certainly growing, in actuality and/or as a topic of interest and importance [20].

\subsection{Planning: Practice, Policy and Governance}

\subsubsection{Why Plan(ning)?}

The practice of planning is the professionalized implementation of planning efforts, processes shaped by and based on the application of planning theories [88,113]. In exploring what the ultimate purpose of planning is, institutional perspectives have positioned it as operating, in effect, as a mode of governing societal actions through processes of "regulation, coordination and control" [114], while others have extended this view to ideally incorporate progressive values linked to social justice and democracy more broadly $[115,116]$. Generally speaking, planning is practiced in order to use knowledge to shape and implement action by informing decision-making. While noting a multitude of theoretical approaches to spatial planning, Morphet [117] acknowledges planning's inherent power as a redistributive social force, with implications for how power itself is mediated. For our purposes, planning occurs through governmentally-sanctioned processes that concern access to goods and services deemed socially beneficial, and which maintain or enhance public health, safety, 
and welfare within a particular place; these provisions are often simplified as public "good(s)" [118].

\subsubsection{Planning's Mandate: Service to the Public Good(s)}

Defining what, exactly, constitutes the public good-much less deciding how to go about achieving, maintaining, or enhancing it-is well-recognized as complex, contentious, and dynamic, involving many diverse stakeholders across multiple levels of society [119-121]. Accordingly, Kunzmann [122] identifies the planning process as one preferably led by the public sector. Numerous climate effects are expected to disproportionately impact (by definition) vulnerable communities, and greater concern for the wellbeing and livelihoods impacted by the products of the adaptation process are, thus, linked closely to planning [123]. Erikson and Brown [124] and Ribot [125] articulate challenges for planning associated with sustainability, resilience, and vulnerability related to uncertainty and complexity in the climate era. Transformative adaptation resulting from effective planning ideally reinforces the legitimacy of the social contract underlying public consent that is granted to planning authorities, ostensibly in their efforts to protect and expand the public good [126].

Planning is understood on basic terms to be a collaborative process that must address what Myers and Kitsuse [127] identified as one of planning's "twin hazards", disagreement (the other being uncertainty), which is confronted through a number of different techniques for conflict resolution in planning, including communication, collaboration, mediation, dialogue, discussion, deliberation, and debate [128-133]. Innes [134] offers an examination of consensus-building as a crucial process for approaching various planning and policy-based disagreements. These serve to discover and define that of which the public good(s) actually consist, and doing so is where the practice of planning partially derives its validity [135]. Owing to numerous factors emerging from climate impacts on the public sector, planning is being deeply reexamined in the context of climate change $[41,88,136]$.

\subsubsection{So ... What Is the Plan?}

A plan involves articulating and orienting towards a vision for the future-what some human geographers refer to as environmental imaginaries. These frame discourses for structuring the relationship of human processes within places, based on societal imperatives and aspirations amounting to the "virtualities" of future states of affairs [137]. This articulation, in the context of producing the "instrument" of a plan, might involve constructing a declarative set of goals, while orienting towards them identifies steps, stages, or strategies for their realization, though both should embody flexibility to changing circumstances, thus possibly entailing "menus" of scenarios that could be encountered [120,138]. This serves to "situate" the future within an as-yet unrealized (imaginary) SES, towards which the plan is intended to guide decision-making $[139,140]$. Strategic plans are generally flexible, longer-term, and less fine-grained than more near-term and discrete project plans, owing partially to greater uncertainty existing in "further off" futures [141].

Plan-making may be challenged as a function of numerous horizontal (sector and actorrelated) and vertical (multi-level governance-related) connections and the legal, regulatory, and institutional standards at play [142-144]. Plans themselves must define and address the community they are intended to serve; and adopted plans represent, to some acceptable degree, the resolution of various disputes and tensions that arise based on the interests of various stakeholders involved, as well as how they may have constructed their own visions for the future $[21,145]$. From an adaptation standpoint, this principle also applies to plans that could impact broader communities, so that adaptation actions undertaken within or for one community do not unduly disadvantage another [45]. Resolving these overlaps, tensions, and tradeoffs is, therefore, part of mediating the planning process that shapes and, subsequently, manifests in the scope and strategy of a given adaptation plan [146]. 


\section{3. 'Sketching' Climate Change Adaptation Planning: Important Features of Interest}

The considerations and theories outlined in the last section illustrate features of planning that are useful in apprehending the fast-emerging practices (and problems) involved in Climate Change Adaptation Planning (CCAP). In this section, we illustrate a conceptual schematic (schema), describing the interplay of notable, generalized features of CCAP (Figure 1). Walker [147] describes a thinking (planning) and implementation (action) phase in adaptive theory applied to policy, to which we add a third phase related to the ongoing assessment of applied work: adaptive management [148]. These echo Peter Hall's [149] trifurcated policy paradigm: overall goal-setting (planning), techniques or instruments (actions), and their "calibration" (management).

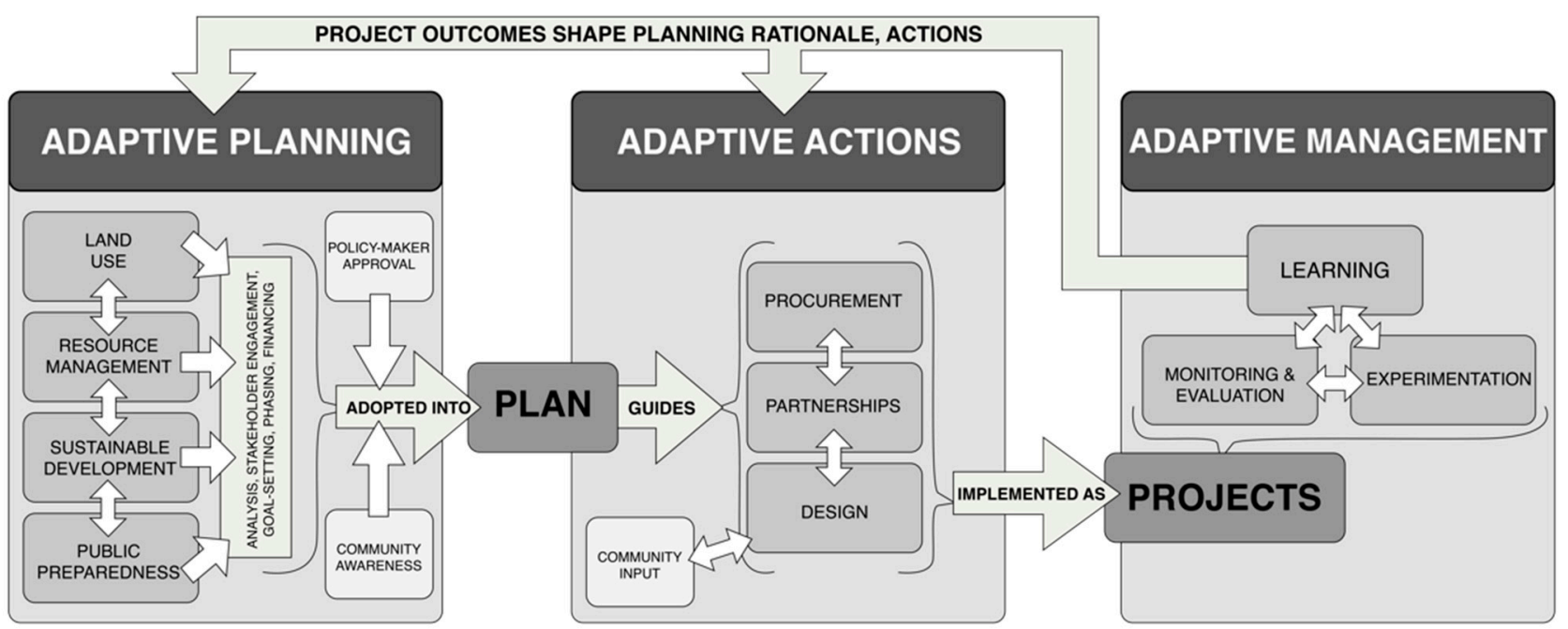

Figure 1. A Climate Change Adaptation Planning (CCAP) Schema. In the Adaptive Planning phase, prominent planning concerns are addressed to produce a plan; Implementation based on guidance from plans yields Adaptive Actions in the forms of projects; these, in turn become subject to Adaptive Management practices for improving upstream and scaled-up efforts.

\subsection{Adaptive Planning}

Aspects of the planning process are inherently anticipatory in nature, wherein complex public policy decision-making occurs in the context of preparing for uncertain future states, thereby naturally engendering adaptive approaches [46]. As a feature of adaptive governance, adaptive planning naturally entails complexities owing to the diversity of actors and actions involved, especially in urban areas [23,150,151]. Anticipatory and planned adaptation within this phase prepare for (instead of react to) future states of affairs, in theory reducing vulnerability and costs [152-154]. Adaptive planning entails stakeholder engagement that takes many forms, but the familiar top-down/bottom-up heuristic is useful in that planners operationalize the interactions of political decision makers in governance (top) and a broader public (bottom), though this group can be defined in various fashions [155,156]. Corfee [145], citing Mitchell [157] and Cash [158], identify requirements for science-policy assessments that inform and influence planning to be deemed publicly acceptable, namely that they be credible, legitimate, and salient.

Plans emerge as products of governance that identify steps for realizing goals in accordance with rules observed by the actor-networks involved, and they gain approval and adoption by passage through the "sluices of democratic and constitutional procedures" $[159,160]$. Adaptive planning ideally embraces learning processes concerned with the structure and effects of the overarching institutional contexts as a useful principle for improving outcomes $[159,161,162]$. Adaptation plans may include financing components or supplementary plans for funding implementation $[163,164]$. "Evolutionary" processes in institutional and governance systems, in which processes of reframing and transforming learning occur, are understood as critical for adaptive and equitable systems and are 
conceptually well-oriented toward adaptation, in general [24,129,165,166]. Limitations in validity assessment and/or forecasting methods may serve to constrain the adaptive planning applications to some extent, though climate change's overall uncertainty implies that flexible, adaptive approaches to planning for it are logical $[9,20,167,168]$.

\subsection{Adaptive Actions}

We borrow from Aylett's [2] description of adaptive governance as relying on distinct adaptation planning and action processes, thus echoing Ostrom's [169] notion of the action situation. We use the term adaptive actions essentially to describe the inception of projects. Adaptation projects in urban areas might entail activities involving construction, such as urban greening to reduce heat island effects, improved shoreline defenses as approaches to coastal zone management, integration of "green" stormwater networks to mitigate upland flooding, and the regional management of "upstream" watersheds, and many municipal infrastructure systems represent adaptation imperatives and opportunities in some fashion [48,170-172]. Yet, adaptive actions might also include community initiatives involving outreach, education, and participation without resulting in changes to the physical environment [173]. Thus, broad CCA interest categories in applied adaptation include land use planning (for reclamation, restoration, preservation, conservation aims, for example), natural resource management regimes (concerning water, for example), sustainable development projects (for housing, infrastructure, and public amenities), and community engagement initiatives (for educational or preparedness purposes) [24,69,120,174-179].

Large, complex, or costly adaptive actions that exceed the capacity of public policy and governance institutions often necessitate NGO and private sector involvement, in which planners operate at the "boundary" between the public and private entities [180-182]. Public-Private Partnerships (PPP) describe arrangements in which collaborative, mutuallybeneficial relationships are assembled; they are common in urban and municipal settings and a subject of interest in sustainable development circles, with noted promise for adaptation, despite their inherent complexities [123,183-186]. Procurement processes and partnerships are generally intended to alleviate capacity constraints of government. These arrangements can distribute risk and integrate diverse skills and resources into projects involving infrastructure, DRR, urban development, and, increasingly, adaptation projects (and which may entail some or all of the aforementioned project goals and concerns), though these arrangements in the context of CCA are still relatively novel [186,187].

\subsection{Adaptive Management}

CCA inherently acknowledges that traditional, linear project implementation "pipelines" for realizing plans may be of limited value in an era characterized by increasing uncertainty and complexity [150]. While ancient in practice, recent interest in sustainable resource use, conservation, and ecosystem management have popularized the concept of adaptive management [91,188-190]. Other authors have stressed the ties of adaptive management to system resilience and flexibility [191]. Drawing on work from Allen [150] and his work with Garmestani [148], Chaffin [44] defines adaptive management as "implementation of management actions as experiments, followed by monitoring, evaluation and adjustment". Because of the prominence of nature-based solutions and green infrastructure in applied adaptation projects, numerous concerns of adaptive management are relevant to CCAP [192]. Adaptive management applies flexible strategies that take into account emergent opportunities and are generally intended as modes of increasing knowledge, thereby arguably building adaptive capacity and aiding adaptive governance $[20,176]$. 
Numerous approaches to understanding change in SESs exist, though central interest in investigating causal processes are especially relevant to planning, a notion termed by Dewey [193] as "experimental knowing". Despite its experimental and flexible nature, adaptive management's potential to induce change (in broader practice and approaches) may be limited by institutional settings where change is itself is problematized or opposed [152]. The experimental underpinning of adaptive management may be useful for learning and information sharing across scales, theoretically aiding in expanding resourcefulness and responsiveness, thereby increasing adaptive capacity $[25,43]$. The potential for specific adaptive actions (in the form of demonstration projects, for example) to broadly inform others might create synergies for syntheses of learning, testing, and adjustment across other sectors and policy realms [152]. Experiments also may be efficient in the sense that small scales (and costs) may generate knowledge that is useful at broader scales, though experimentation itself-especially in large (landscape), complex (urban), and dynamic (climate-related) contexts_-presents numerous challenges [148,194]. While "scaling up" projects for broader regional application remains complex and daunting [195-197], Hallegatte's [20] identification of the desirable "low regret" quality of adaptation strategies and projects represents obvious conceptual correspondence with experimentation.

Adaptive management also presents opportunities to improve the planning process by incorporating enhanced social inclusiveness, including the dissemination and sharing of information $[198,199]$. Monitoring that produces data useful for policy consideration is subject to a "reuptake mechanism", whereby conditions observed in adaptation actions may then inform improved planning practices of future or concurrent ones [145]. Fankhauser [45] asserts that adaptation potential is predicated on having "room" to change behavior. By providing the public, planners, and policymakers with real-time, real-world feedback that illustrates how selected adaptive actions are functioning, the "room" for adaptation may become better-parameterized through the reduction of uncertainty (especially relevant in the climate change era) provided by experimental observations. The "feedback loops" inherent to adaptive management suggest that CCAP is, thus, better conceived as looped processes, which are common in conceptualizations of SESs $[129,161,200]$.

\section{Zooming Out: CCAP in Broader Context}

Partially owing to the varied and multi-scale concerns and methods of practice, the literature exploring what CCAP is and how it operates contains no shortage of concepts and terminology for intellectualizing relevant ideas, themes, theories, and describing a diversity of applied work. While it is beyond the scope of this article and our study to exhaustively compare and square the myriad notions and constructs put forth to describe CCA, we offer a summary of important and interesting concepts, which we synthesize in this section. We then construct a conceptual, graphic framework (Figure 2) that strives to integrate these concepts into a holistic logic, offering a mode of rendering the important ideas and their relationships in a conceptual "space" that captures essential ideas of how important features and forces of CCA interact. 
(a)

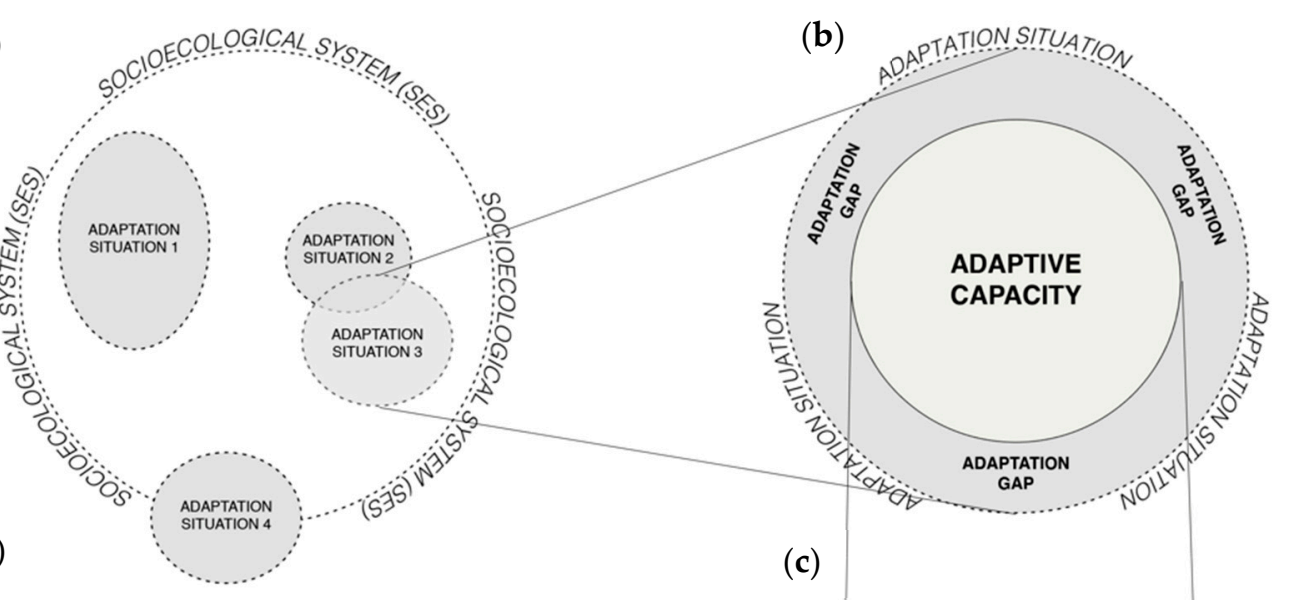

(d)

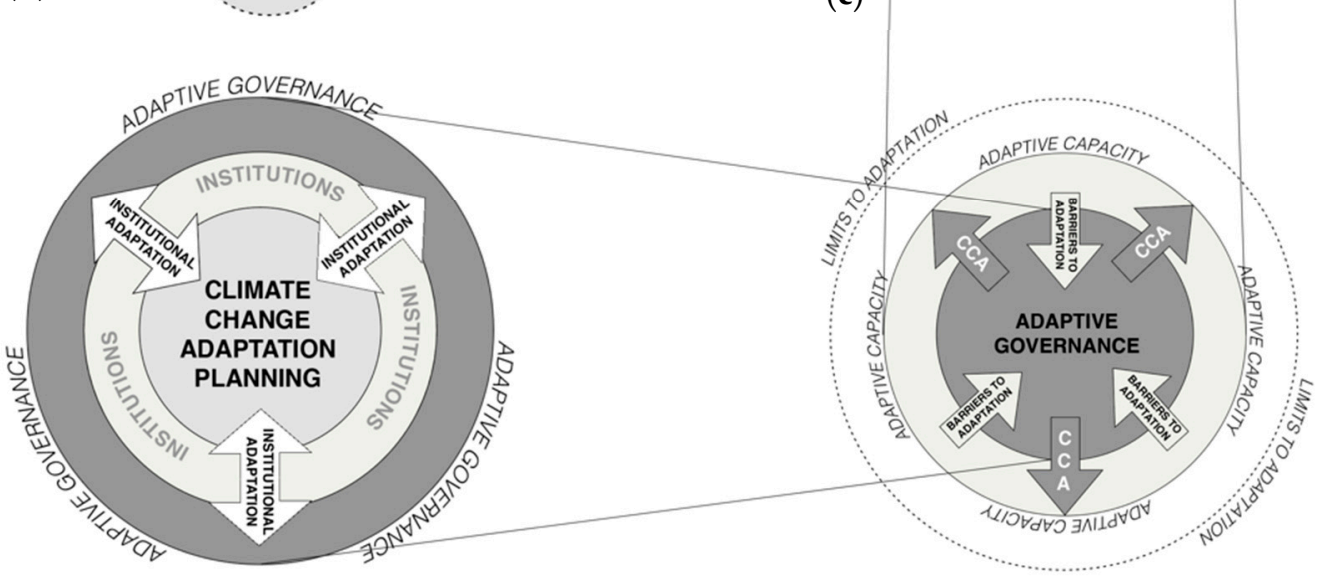

Figure 2. A framework displaying the 'nested' and 'coupled' nature of concepts and interactions of importance in climate change adaptation literature. Arrows denote force directionality, indicating how efforts or concepts "push or pull" towards and/or against other conceptual features or 'spaces'. A 'glossary' of key terms from the framework above. A theoretical discussion follows. (a) The socioecological system (SES) forms the basic conceptual unit of consideration for framing the adaptation situation. Numerous and interacting adaptation situations may exist within a given SES, or overlap, or "spill" into others. Adaptation Situations are characterized by features of the SES, including those in sociotechnical (human-based) and biophysical (natural setting and context-based) domains, which interact. Phenomena in the biophysical domain engender sociotechnical efforts to establish or expand ("realize") adaptative capacity. (b) Adaptive capacity is generated by sociotechnical efforts to adapt to biophysical features of the adaptation situation. In general, it is realized by building resilience and reducing vulnerability. An adaptation gap exists in the portion of the adaptation situation that lies beyond the adaptive capacity realized within it. It represents the amount of unrealized adaptive capacity. (c) Adaptive governance describes sociotechnical efforts in shaping the adaptation situation: when effective, adaptive governance increases adaptive capacity, thereby, ideally, shrinking the adaptation gap. Maladaptive (ineffective or counter-productive) efforts reduce adaptive capacity. Barriers to adaptation are produced, encountered, and addressed by the sociotechnical and biophysical domains, and in their interactions. Barriers constrain and shrink adaptive capacity, often by hindering adaptive governance or exceeding its reach. Limits to adaptation describe the extents of possible adaptation efforts, beyond which increasing adaptive capacity is (actually or considered) infeasible or impossible. Limits may be unknown. (d) Adaptive governance employs formal practices (planning) as modes of realizing efforts, and it is shaped by broader characteristic cultural features and processes (institutions). Its efficacy is the sum of institutional and planning efforts performed in the interest of CCA. Integrated adaptation refers to the coordination and feedback between adaptation planning-based practices and institutional processes of adaptive change that. 


\subsection{Conceptualizing Climate Change Adaptation: Framework Features and Forces}

\subsubsection{Context: Defining Social-Ecological Systems}

Pioneering work by Berkes and Folke $[13,58]$ to articulate the interactive dimensions and interplay between humans and their environments introduced the keystone concept of social-ecological systems (SES), based partly on work regarding the systematic nature of aspects of the human-nature interaction illustrated by concepts, including vulnerability, resilience, and sustainability $[17,65,201]$. These insights became key components of numerous interpretive framework approaches to understanding socioecological interdependencies [13]. Of particular importance to planners is that SESs are inherently spatially contextualized. That is, because of the entanglement of particular and countless effects of some given environmental situation on sociotechnical (human) systems (and vice versa), they are understood as being in some way at play within a spatially distinct or discernible setting. However, this quality is also, by implication, malleable; and its definition or delimiting is based partially on the interest and perspective of the individual(s) considering or using it as a construct for understanding, planning and managing actions to intentionally alter SESs—-the basis of adaptation [200].

\subsubsection{Problem: Emergence of Adaptation Situations}

Insofar as SESs contain or capture the dynamics between human drives to utilize natural resources and systems, dilemmas stemming from these drives and the capacity of the environment to accommodate them emerge constantly [202,203]. This produces phenomena in which the social and ecologic system aspects relate (or are situated with respect) to one another, generally impelling tensions regarding resources and governance, thus engendering situations in which, according to Ostrom [169], actions may be taken to address or resolve them - generating the concept of the action situation [204-206].

The magnitude of climate change on earth's biogeophysical systems has compelled some authors to refine Ostrom's original notion to define adaptation situations as a particular form of action situation [118]. Citing previous work, Bisaro and Hinkel [207] describe the adaptation situation as one involving "one or more actors interacting within a common biophysical and institutional environment in which outcomes are altered through climate change". This implies that social features of the situation may be interested in adapting to climate change, as well as that, regardless of their interest or efforts, outcomes will be shaped by biophysical effects of climate change, which resonates with other scholarship describing the centrality of human endeavors to shape the adaptation situation [208-210].

\subsubsection{Manifesting Adaptive Capacity: Adaptive Governance}

The sociotechnical (human) features of SESs address the adaptation situation by making decisions about taking actions. These actions amount to Smit and Wandel's [68] description of adaptation(s) as the "manifestation of adaptive capacity". The dominant means by which adaptive capacity is manifested by the sociotechnical entities of an SES is through adaptive governance, in large part because of the scale at which governmentallyorganized action can operate, [24,211,212]. Chaffin [44], in reviewing adaptive governance and synthesizing the perspectives of others, describes adaptive governance as emerging from the search for "modes of managing uncertainty and complexity in SESs". Adaptive governance might be understood as the exercised portion of adaptive capacity-the part that "people use" [213]. Accordingly, depending on how and when adaptive capacity is used, it is dynamic over time, unfolding across scales in "coupled cycles of change" [68,214]. While we examine adaptive governance through the lens of climate change, concepts from theories of evolutionary governance may also be useful to consider and apply.

Though adaptive capacity is doubtless considered a desirable quality to possess, the particular and various ways in which adaptive governance is conceived and practiced may give rise to effects that tend to reduce or constrain adaptive capacity; or outcomes that are maladaptive $[136,215,216]$. Likewise, while adaptive capacity may reflect or express component qualities of the adaptation situation, including vulnerability, resilience, 
and sustainability, understanding how adaptive capacity is designed or generated (or not) remains complex [16,214]. Carter [41], drawing upon work by Rosenzweig [217], after Mehrotra [218], positions adaptive capacity in relation to vulnerability and hazards, the interactions of all three in essence serving to define risk. In this view, a system's adaptive capacity serves as a kind of counterweight against its vulnerability. While capacity intuitively refers to the amount of something (of which one might possess more or less), governance is not the only source of adaptive capacity, which can be possessed or provided by non-human features of an adaptation situation, or through non-governance-mediated human actions $[43,162]$. We focus on adaptive governance because of its centrality to CCAP.

\subsubsection{Aspirations: The Adaptation Gap}

Lying between the optimal and actual adaptive capacity characterized within a given adaptation situation is a "gap", wherein the potential actions and outcomes of becoming optimally or fully adapted have not (yet) been realized. Moser and Eckstrom [215], echoing Burton [219], note this as a form of adaptation deficit. In describing the analytical methodology of gap analysis for assessing climate hazards, Chen [220] defines the adaptation gap as a "difference between existing adaptation efforts and adaptation need". The United Nations' recently published Adaptation Gap Report focuses on nature-based solutions in conceptualizing and further defining the adaptation gap, though previous volumes with different emphases all include the adaptation gap as a centralizing theme [221]. Numerous complications arise from attempts to quantify subjective, complex, and dynamic features of an adaptation situation that, in theory, define the adaptation gap, including the potential "unknowability" of what, precisely, the gap actually entails and includes [98,222]. Nonetheless, the concept of the adaptation gap is intuitive and useful in the same sense that adaptive capacity is, the former describing an amount of adaptation work to be done, and the latter describing the work that has been done (thereby establishing existing capacity) or can be done as a function of this work. If adaptive governance and other adaptation-oriented sociotechnical efforts are understood as seeking to build adaptive capacity, what forces and phenomena serve to constrain or diminish it?

\subsubsection{Challenges: Barriers and Limits to Adaptation}

A subject of broad interest is barriers to adaptation. Moser and Eckstrom [200] define these as "impediments that can stop, delay, or divert the adaptation process", specifying that they may be surmounted through "concerted effort, creative management, change of thinking, prioritization, and related shifts in resources, land uses, institutions, etc.". Work from Anderies [16], Ostrom [223], and Adger [224] helps situate this concept within the SES literature which, by extension, we project and integrate as features of adaptation situations [207]. Some authors have invoked the notion of adaptation "obstacles", which we consider essentially analogous to barriers [145]. Barriers arise at different stages and levels of adaptation; and they may emerge because of features of governance itself-potentially influencing exactly how adaptive such governance can claim to be-and, by extension, defining its degree of adaptive capacity [69,152,200]. Importantly, Bisaro [225], questioning the utility of the concept, points out that barriers that are easily identified might mask larger, structural, and institutional forces that produce the effect(s) of barriers without presenting obvious modes of addressing them.

A common phenomena that arises from and promulgates barriers to adaptation (thus, in theory, reducing adaptive capacity) is path dependency, which occurs when institutions or organizations "fail to effectively adapt established practices to face changing circumstances", a pattern of behavior observed across numerous sectors and organizational endeavors, though maladaptive outcomes are a common effect-with obvious and sectorspecific implications for CCA, especially in urban settings [2,226,227]. From an economic perspective, situations in which inferior practices perpetuated by path dependency may serve to "lock-in" inefficient (or maladaptive) behaviors and outcomes [228]. Citing Pierson [229] and Wilson [70], among others, Fischer [69] notes path dependency as a kind 
of inertia that results when future actions are shaped in profound or pernicious ways by previous ones. Path dependency, in this sense, is of particular importance for CCAP because of planning's stepwise, cyclical, discursive, and constantly-unfolding nature; the ubiquity of decision-making points and processes therein; diverse sets of actors taking part in the process(es); and the variety of "embedded" cultural features and forces that steer and constrain them [186,230-232].

Whereas the notion of barriers (and obstacles) naturally conjures ideas about surmounting them, limits to adaptation refer to bounds that describe "level(s) of adaptive capacity ... that cannot be surpassed", potentially defining the boundary between acceptable and intolerable risks, and which might require transformative change to avoid [85,233]. Barnett [226] distinguishes between "hard" limits that are essentially defined by the environment and "soft" ones that are socially determined and, thus, theoretically malleable. Indeed, Eisenhauer [73], in defining these limits as "factors that prevent adaptation from succeeding", points out that they have been articulated as both objectively identifiable (as in the case of certain biotic and economic examples) and, from a more constructivist perspective, presenting as difficult-to-define endogenous effects emerging from societies' "goals, values, risk perceptions and actions". Limits are perhaps also worth considering as "blended" between hard and soft characterizations because sociopolitical conceptualizations of limits emerge in response to environmental ones, which may then be redefined by human intervention. In general, limits define the extent to which adaptive capacity could be realized-apart from how effectively barriers are overcome in the practice of adaptive governance (to increase adaptive capacity). Again, this resonates with Adger's [224] view that limits are situational thresholds beyond which "adaptation actions fail to protect things stakeholders care about", which we understand to include non-physical "things", such as social cohesion, morale, trust in institutions, etc.

\subsection{CCAP: Integrating Institutional Adaptation}

\subsubsection{The Role of Institutions}

Gupta [4] elegantly renders institutions as "social patterns", while a more expansive view, according to Oberlack [74], citing several others, articulates institutions as "rules and procedures that structure action situations within which individual and collective decisionmaking [is affected to] constrain, enable and incentivize actions; link individual actions, events and outcomes; distribute authority and power; define reciprocal rights and duties; and shape beliefs, motivations and social learning" [24,169,234,235]. These may be formal or informal [159]. Vatn [236] describes the invisible or even unselfconsciously natural instantiation of institutions in behavior as conventions that are observed, referencing work by Crawford and Ostrom [237], to compose a "grammar" of institutions and their functions. Institutions might be understood as self-reinforcing "regularities": patterns of behavior evident in networks of social actors who "tacitly create [them] to solve a wide variety of recurrent problems" [238]. Yet, despite regularities and recurrences, institutions are not static; they "distribute obligations and entitlements to resources as well as the power to change such obligations and entitlements" [239]. Though they may be nonmaterial (informal), institutions reify actual, tangible outcomes.

Institutional analyses focused on resources (components or products of the environment) and how the notion of property (which entails ownership, often of the landscape itself) factors into their management, is a well-established field of institutional interest, and planning has been articulated as a mode of "bundling the rights" of ownership associated with property in this sense [240]. From an economic perspective, the linkages between humans and their environment are mediated by countless rules that shape and reinforce beliefs and values, but these are dynamic and responsive [241]. Where public policy is concerned, this dynamic quality of institutions has important implications because the question of how power and influence is distributed within society-including this critical capacity to alter existing situations and arrangements-is of enormous importance in the climate change era [74], insofar as planning efforts are understood as being shaped by 
larger cultural and institutional forces, and these may fail to present obvious, accessible, and discrete decision-making processes themselves [172,225].

\subsubsection{Institutions and Change}

In theorizing about the evolutionary nature of governance, Van Assche [166] positions institutions as being designed for change, even postulating that the essence of democracy lies in the "rules of self-transformation; rules to change the rules". As institutions occupy important features of SESs and spatial discourse generally, they are tightly linked with conceptions of the environmental imaginary [242], entailing consideration of the distribution and access to power and influence involved in its realization, recalling Bromley's [239] obligations and entitlements [243]. In other words, institutions structure what is possible based partially on how society mediates the tensions arising from multitudes (citizens, actors) shaping and sharing something more unified (the environment) [244]. Institutions influence aspirations (for a more healthy and just environment, for example), even while subject to inertia (perpetuating the status quo), and the outright resistance to change, termed the precautionary principle, which is important in situations involving uncertainty [245-247]. Similar to the concept of path dependency in organizational endeavors, institutional inertia and "lock in" may occur when regimes and patterns of behavior become ossified due to various factors $[229,241]$. Institutions within or across SESs may constrain or delimit the actions of organizations by conformation and homogenization, producing institutional isomorphism [248], which may be induced by coercive, mimetic, or normative means [142]. Storbjörk and Hedrén [172] describe clashing cultures, knowledge claims, and cross-sectoral integration problems as several notable barriers to institutional change.

While approaches to determining how institutions resist change (in inertial, oppositional, and isomorphic ways) are evident, factors that instigate change within and across institutions are complex to identify, perhaps owing to requisite "concatenations" of underlying mechanisms [249,250]. Hodgson [251] identified two dominant institutional modes: agent-sensitive and agent-insensitive, the latter describing an institution in which significant change affected by institution-shaping actors (agents) is unlikely or difficult. Individuals, organizations, and governance structures that cut across public and private sectors constantly respond to environmental change (thereby engendering change); thus, environmental change does not occur in an "institutional vacuum" [249,252]. Influential individuals (leaders) [253], sociopolitical mobilization [254], and/or catalytic or vivid events [255] that impose or focus urgency upon some situation may induce institutional change by creating, though other factors have been identified as important "drivers" precipitating change dynamics $[10,249,256]$. Aggregating these behavioral changes across scales and social structures-and mediating or coordinating them through planning mechanisms-, in turn, changes the institutional environment itself, in theory providing conditions for institutional adaptation [117]. Planning that attempts to engage these institutional change dynamics confronts a duality in that institutions are both behavior patterns "out in the world" (actions) and internal ones "in the head" (thoughts and feelings), which obviously presents complexities to planners attempting to derive institutional origins [257,258]. All of these qualities speak to the difficulty in clearly formalizing or mapping institutional dynamics, made especially complex in a situation in which the underlying environmental context is also in a state of flux.

\subsubsection{Institutions, Climate Adaptation, Planning}

Smit and Wandel [68] note that adaptive capacity may be increased through improvements in technology and/or institutions, while Rodima-Taylor [123] echoes Koppel's [259] position that technological innovation is induced by institutional change. Christensen [102] considers technology in the context of planning to be the "knowledge of how to do something"-literally, the means. Our CCAP schema illustrates that these means might be expanded by integrating adaptive principles into planning that make it more "nimble" (thus, resistant to path-dependence). Yet, how these qualities relate to an institutional 
adaptation discourse remains complex, in part owing to the need to disentangle the functions and mechanics of institutions themselves [10,260,261]. In developing a framework for assessing institutional adaptive capacity, Gupta [4] identifies two core characteristics: one essentially describing their inherent, extant qualities; and the second relating to the degree to which they "allow or encourage" their own (institutional) change, essentially describing adaptability itself. The rate of change, or timing, also matters: disparities between non-institutional changes that occur within SESs and that at which institutions are fundamentally able to affect change may lead to missed opportunities, including from a lack of timely collaboration and cooperation $[4,215,226]$.

Roggero [208] explores how one aspect of institutional change is positioned with respect to CCA in his iteration of Hagedorn's [234] notion of integrative institutions (that address climate-related interdependencies) versus segregative ones (that focus only on climateimpacted resources under their effective purview). Institutional complexity itself may work against institutional change or adaptation simply as a function of the increased "work" required to do so in complex networks, though structured learning processes may be useful $[24,155,262]$. Informal, 'behind-the-scenes' "shadow" processes may be important factors for inducing institutional change [175], in addition to the identification and inception of "additional or adjusted institutional design propositions" to address climate uncertainties and complexities [161].

A critical question for CCAP and its role in building adaptive capacity seems to concern the scope of its influence and intentions, particularly in relationship to institutional forces that define, delimit, and direct them, as well as how these may differ or mesh with planning practices and processes as traditionally understood. For example, failures to adapt may be due to issues of governance more so than the planned, technical implementation of applied adaptation efforts, reflecting complexity inherent to multi-level governance $[24,263,264]$. Patterson's [10] work investigating dimensions and possible drivers of institutional adaptation in urban governance reveals that, in formal terms, "planning" is limited in its role: for example, it is not the job of planners to cultivate charismatic leaders, nor to foment community pressure (much less political disruptions), even though these may occur partially as a function of adaptation planning. The lack of real or perceived alignment of institutions with climate change adaptation risks the governance processes for achieving it being less adaptive and/or less strategic than optimal: a condition describing or producing institutional "voids" [256].

\section{Discussion}

\subsection{Central Insights}

As explored and illustrated in this review, planning and institutional domains are being challenged or are changing because of the emergence, intensity, and importance of climate change within policy and governance spheres. The core goal of this review is to explore complicated topics across several domains and, based on thematic and conceptual linkages prominent in the literature, to construct an integrative perspective to increase clarity in comprehension of complex and related topics relevant to CCA. Several insights based on this work are notable. First, important concepts of climate change literature have been increasingly encountered and integrated into spatial planning practices, which have led to distinct forms of planning. Our CCAP schema demonstrates how, for example, uncertainty is being addressed not only as an increasing "fact of life" for planners to manage but one that can be understood and approached opportunistically and as a force driving innovation and learning processes that increase adaptive capacity. In other words, the emphasis and engagement with climate change issues is leading to adaptation in the practice of planning itself.

Second, prominent and complex concepts of interest evident in climate change literature can be organized into a holistic construct that displays important tenets of the research, and displayed in such a fashion as to clarify their interplay, as through the proposed framework. These interplay may take the form of positional properties of features 
within a framework that group or separate concepts, nest or embed them in one another, or imply some connective linkage(s) or couplings. They can also be rendered in mechanistic terms, where dynamics of some feature of interest logically or implicitly affect others, thus illustrating causal relationships. These are of particular importance in adaptation work in a similar fashion to features of our CCAP schema, in that, fundamentally, being adaptive entails processes of feedbacks and responses in systems. Because our framework's foundational feature (within and through which other features interact) are SESs, we can intuitively grasp this systematic structure and behavior. The framework, in this regard, is useful in two primary ways: it organizes and simplifies information; and it provides its own logic that is both emergent (arising from themes and ideas in the literature examined) and can be utilized, altered, or critiqued by practitioners for case-specific or applied work, or as a basis for expansion or alteration through introducing additional or different theoretical components.

Finally, as a function of the deeply complex, subtle, and dynamic nature of institutions (including merely identifying or agreeing upon them), we display the limits of the framework; prompt consideration of how planning and institutions are, in theory and reality, bound together; and provide context for considering relevant connections or patterns as theses domains unfold and interact through CCA endeavors. For example, we discuss that organizational path dependency and institutional lock-in both serve to reduce adaptive capacity, while the modes of surmounting these barriers to adaptation are nonetheless domain-distinct, in terms of the means for assessing, addressing, or ameliorating them. Likewise, planning and institutions must be understood in a temporal context in important ways: planning because its legitimacy and efficacy depend on the results of its implementation and "follow through"; and institutions because their social utility, acceptance and adherence are derived, at least partially, by way of their durability. The examination of key features of the climate change era, namely uncertainty and change itself, present vexing questions and prompt provocative, perhaps even subversive, perspectives from which to consider the practice of planning and its institutional context.

\subsection{Adoption, Application, Adaptation of the Framework}

This article seeks to articulate the ways in which important concepts relevant to climate adaptation might be more clearly differentiated and understood in their relational dynamics, partially through illustrating schema that can be adapted to various actual situations or case studies, and linking these with prominent themes and patterns from our literature review. An overarching challenge in CCA, planning, and institutional change (especially) is measuring or quantifying the magnitude or effects of concepts that, to some extent, resist or defy efforts to do so. Certain aspects of SESs are, after all, based on informal, constantly-changing, and nonmaterial qualities with which it is, nonetheless, important to grapple. Our "schematizing" of concepts in ways that can be visualized, to some extent, might provide interesting opportunities for researchers seeking to understand how individuals (within or across organizations, levels of government, and/or demographic groups) comprehend, or (literally) "picture", some of these concepts.

Future use of the framework along these lines might take the form of research employing templates that are used to gauge (for example) how different groups render adaptive capacity inside an adaptation situation, define magnitudes of effects for various barriers; order hierarchies of adaptation planning issues, "connect" causal influences or tensions between features and how they are situated relative to others, or articulate the "distance(s)" they imagine limits lie from adaptive capacity. Clearly, these exercises would yield abstractions: sketches or diagrams, that stand in for more nuanced work. Yet, these might reveal insights and/or patterns valuable to managers seeking to understand institutional or organizational dynamics, public sentiment, or differences across divisions, or even the age or career seniority of individuals. While not the focus of this article, social science methods applied to constructing impressions and understanding of how various groups apprehend the concepts explored here-and their relationships to each other-may be illuminating. A 
consistent theme of this research seems to be that what people believe is possible (and the institutional ramifications therein) is strongly linked with problem definition and framing, with obvious impacts on decision-making and commensurately dramatic implications for CCAP.

\subsection{Critical Considerations and Questions}

One of the appeals of institutions that are not only adaptive but well-integrated into CCAP is that their influence and capacity to "structure ... political decision-making ... [and] shape practices and behaviors" is understood as being vital for the success of largescale, strategic efforts necessary in complex urban settings $[10,23,137]$. In this context, the utility of local knowledge and local institutions has been emphasized as a driver of adaptive capacity but also as processes, not merely information or rules (content) $[68,265,266]$. In one sense, planning is a practice of more than instrumentalizing content; it inherently represents engagement with ongoing processes. Yet, precisely because planning entities (individuals, agencies, departments, divisions, authorities) are empowered by and within overarching institutional milieus, questions emerge about planning as a force for transformational, fundamental change in the ongoing adaptation quest, which some see as amounting to the proposition of a paradigm shift for planning itself [47]. In other words, can planning "unlock" institutions from nonadaptive tendencies, and to what degree?

We have examined the relationships between these concepts and their underlying theories to situate planning in a critical light, insofar as we question its agency and the scope of its traditionally-conceived responsibilities. Planning, in the face of massive environmental change and uncertainty, may itself obscure the clarity of future visions and complicate the steps for manifesting them, in no small part due to institutional inertia and dynamics. That is, uncertainties rooted in the institutional domain may amplify overall situational uncertainty and complicate planning processes attempting to address it. Dovers [267] points out that even constructing an understanding of the limits to adaptation is fraught in part because of the institutional dimension, whose sheer complexity grows with the scale considered [268]. With climate change altering resource regimes and shaping the public good(s) of citizens linked through institutional behavior and (ideally) aligned through adaptation planning practices, questions about how common-pool resources and common-pool institutions can or should shape planning's role in allocating entitlements and obligations emerge [60,263,269-271]. This, in turn (and in ways beyond the scope of this article), ensnares any number of private sector considerations and the need to, among other things, understand how planning and institutions are positioned to address or adapt to markets relevant in adaptation $[66,143]$.

\section{Conclusions}

Our review examined important concepts related to the CCA plight by examining the theoretical and applied linkages between the practice of spatial planning and role of institutions in the governance of adaptation, with an emphasis on issues and dynamics broadly relevant in urban regions. Through this process, we sought to illustrate and situate prominent themes and concepts in climate adaptation work that connect to engage planning and institutional dynamics, as well as their effects on SESs, which Berkes and Folke originally termed the "linkages between ecosystems and institutions" [13]. Epstein expanded on this concept and considered the differentiation between social and ecological systems as reconciled by "fitting" them together through institutions themselves; in doing so, this revealed strengths and limitations of the institutional couplings of these systems [14]. Planning, as we have discussed, represents a mode of instrumentalizing adaptive governance largely in the interest of increasing adaptive capacity; and, in the climate era, our schema demonstrates how planning employs various techniques to do so in the context of uncertainty and change, in fact, by embracing it and approaching it opportunistically. Likewise, our framework illustrates the nested and linked-or coupled-mechanics of planning to larger concepts and displays how their interconnections might be understood. For their 
part, institutions, while playing important roles in shaping and constraining planning and defining various aspects of SESs, remain difficult to fully comprehend and describe when the same considerations of uncertainty and change characterize the (conceptual) landscape in which they are realized.

In his treatise articulating the global, intergenerational ethical and moral implications of climate change, Stephen Gardiner [272] identifies institutional inadequacy as a key characteristic; one that, for various reasons, cannot simply be overcome by better governance. This article situates adaptation planning as a critical link between governance and institutions: in the case of the former, as a "downstream" tool for facilitating policy decision-making; in the latter, by triggering feedback from features of the SESs that have "upstream" implications for the "rules of the game" themselves, which define and constrain what futures are considered possible or desirable [273]. Planning, as a field seeking to integrate science and knowledge into decision-making, is surely constrained in its capacity to do so by various political and institutional arrangements and realities, though Roggero [209] asserts that organizing knowledge in "institutionally meaningful ways can advance ... understanding of the link between institutions and adaptation". What precisely constitutes institutional meaningfulness in the context of climate change remains complex, dynamic, and, surely, case-specific, to some degree.

Insofar as we consider institutions to be collectivized social patterns of behavior that are "rendered durable" over time by routine and habits, the task for planning to break from reinforced tendencies that reduce adaptive capacity seems pressing [251,258]. These reflections position planning in a crucial position that prompts consideration about the nature or characterization of planning entities themselves: are they primarily agents within Hodgson's [251] reckoning (to whom institutions may be sensitive/responsive in terms of change), or merely a means by which those agents interact? If they fall into the former category (or if they are understood to be both), the question of intent emerges: is it the role and responsibility of planning to actively, aggressively attempt to alter-or even do away with -institutions in light of the knowledge planning inevitably encounters and frames? If so, which institutions? In what circumstances, to what degree, why, and-critically-how? While this last question involves what Dover [267] calls the practicalities of institutional change, the challenge for adaptation planning in the 21 st century may be as much about principles as practicalities.

Author Contributions: Writing—original draft, N.K.; Writing—review \& editing, K.H. All authors have read and agreed to the published version of the manuscript.

Funding: This research received no external funding.

Conflicts of Interest: The authors declare no conflict of interest.

\section{References}

1. Nordgren, J.; Stults, M.; Meerow, S. Supporting Local Climate Change Adaptation: Where We Are and Where We Need to Go. Environ. Sci. Pol. 2016, 66, 344-352. [CrossRef]

2. Aylett, A. Institutionalizing the Urban Governance of Climate Change Adaptation: Results of an International Survey. Urban Clim. 2015, 14, 4-16. [CrossRef]

3. Einecker, R.; Kirby, A. Climate Change: A Bibliometric Study of Adaptation, Mitigation and Resilience. Sustainability 2020, 12, 6935. [CrossRef]

4. Gupta, J.; Termeer, C.; Klostermann, J.; Meijerink, S.; van den Brink, M.; Jong, P.; Nooteboom, S.; Bergsma, E. The Adaptive Capacity Wheel: A Method to Assess the Inherent Characteristics of Institutions to Enable the Adaptive Capacity of Society. Environ. Sci. Policy 2010, 13, 459-471. [CrossRef]

5. Wang, Z.; Zhao, Y.; Wang, B. A Bibliometric Analysis of Climate Change Adaptation Based on Massive Research Literature Data. J. Clean. Prod. 2018, 199, 1072-1082. [CrossRef]

6. Tribbia, J.; Moser, S.C. More than Information: What Coastal Managers Need to Plan for Climate Change. Environ. Sci. Policy 2008, 11, 315-328. [CrossRef]

7. Berrang-Ford, L.; Pearce, T.; Ford, J.D. Systematic Review Approaches for Climate Change Adaptation Research. Reg. Environ. Chang. 2015, 15, 755-769. [CrossRef] 
8. Ford, J.D.; Pearce, T. What We Know, Do Not Know, and Need to Know about Climate Change Vulnerability in the Western Canadian Arctic: A Systematic Literature Review. Environ. Res. Lett. 2010, 5, 014008. [CrossRef]

9. Giordano, T. Adaptive Planning for Climate Resilient Long-Lived Infrastructures. Utilities Policy 2012, 23, 80-89. [CrossRef]

10. Patterson, J.J. More than Planning: Diversity and Drivers of Institutional Adaptation under Climate Change in 96 Major Cities. Glob. Environ. Chang. 2021, 68, 102279. [CrossRef]

11. Lawrence, D.P. Planning Theories and Environmental Impact Assessment. Environ. Impact Assess. Rev. 2000, 20, 607-625. [CrossRef]

12. Ndubisi, F. Ecological Planning: A historical and Comparative Synthesis; Johns Hopkins University Press: Baltimore, MD, USA, 2002

13. Fikret, B.; Carl, F. Linking Social and Ecological Systems: Management Practices and Social Mechanisms for Building Resilience; Cambridge University Press: Cambridge, UK, 1998.

14. Epstein, G.; Pittman, J.; Alexander, S.M.; Berdej, S.; Dyck, T.; Kreitmair, U.; Rathwell, K.J.; Villamayor-Tomas, S.; Vogt, J.; Armitage, D. Institutional Fit and the Sustainability of Social-Ecological Systems. Curr. Opin. Environ. Sustain. 2015, 14, 34-40. [CrossRef]

15. Colding, J.; Barthel, S. Exploring the Social-Ecological Systems Discourse 20 Years Later. Ecol. Soc. 2019, 24, 2. [CrossRef]

16. Anderies, J.M.; Janssen, M.A.; Ostrom, E. A Framework to Analyze the Robustness of Social-Ecological Systems from an Institutional Perspective. E S 2004, 9, art18. [CrossRef]

17. Gallopin, G.C.; Gutman, P.; Maletta, H. Global Impoverishment, Sustainable Development and the Environment: A Conceptual Approach. Int. Soc. Sci. J. 1989, 121, 375-397.

18. Aldo, L.; Schwartz, C.W. A Sand County Almanac: With Other Essays on Conservation from Round River; Oxford University Press: New York, NY, USA, 1949.

19. Albrechts, L. Strategic (Spatial) Planning Reexamined. Environ. Plan. B Plan. Des. 2004, 31, 743-758. [CrossRef]

20. Hallegatte, S. Strategies to Adapt to an Uncertain Climate Change. Glob. Environ. Chang. 2009, 19, 240-247. [CrossRef]

21. Levin, K.; Cashore, B.; Bernstein, S.; Auld, G. Overcoming the Tragedy of Super Wicked Problems: Constraining Our Future Selves to Ameliorate Global Climate Change. Policy Sci. 2012, 45, 123-152. [CrossRef]

22. Toimil, A.; Losada, I.J.; Nicholls, R.J.; Dalrymple, R.A.; Stive, M.J.F. Addressing the Challenges of Climate Change Risks and Adaptation in Coastal Areas: A Review. Coast. Eng. 2020, 156, 103611. [CrossRef]

23. Castán Broto, V. Urban Governance and the Politics of Climate Change. World Dev. 2017, 93, 1-15. [CrossRef]

24. Pahl-Wostl, C. A Conceptual Framework for Analysing Adaptive Capacity and Multi-Level Learning Processes in Resource Governance Regimes. Glob. Environ. Chang. 2009, 19, 354-365. [CrossRef]

25. Bulkeley, H.; Castán Broto, V. Government by Experiment? Global Cities and the Governing of Climate Change. Trans. Inst. Br. Geogr. 2013, 38, 361-375. [CrossRef]

26. Rasmussen, D.J.; Oppenheimer, M.; Kopp, R.E.; Shwom, R. The Political Complexity of Coastal Flood Risk Reduction: Lessons for Climate Adaptation Public Works in the U.S. Earth's Future 2021, 9, 1-19. [CrossRef]

27. Meadows, D.H. The Limits to Growth: A Report for the Club of Rome's Project on the Predicament of Mankind; Earth Island: London, UK, 1972; ISBN 0-85644-008-6.

28. Meadows, D.H.; Randers, J.; Meadows, D.L. The Limits to Growth: The 30-Year Update; Chelsea Green Pub.: Hartford, VT, USA, 2004; ISBN 1-931498-51-2.

29. Herrington, G. Update to Limits to Growth: Comparing the World3 Model with Empirical Data. J. Ind. Ecol. 2021, 25, 614-626. [CrossRef]

30. Gualini, E. Planning and the Intelligence of Institutions: Interactive Approaches to Territorial Policy-Making between Institutional Design and Institution-Building, 1st ed.; Routledge: London, UK, 2001. [CrossRef]

31. Ritchie, J.; Lewis, J.; Nicholls, C.M.; Ormston, R. Qualitative Research Practice: A Guide for Social Science Students and Researchers, 2nd ed.; Sage: London, UK, 2014.

32. Webster, J.; Watson, R.T. Analyzing the Past to Prepare for the Future: Writing a Literature Review. Manag. Inf. Syst. Q. 2002, 26, xiii-xxiii.

33. Paré, G.; Trudel, M.-C.; Jaana, M.; Kitsiou, S. Synthesizing Information Systems Knowledge: A Typology of Literature Reviews. Inform. Manag. 2015, 52, 183-199. [CrossRef]

34. Jabareen, Y. Building a Conceptual Framework: Philosophy, Definitions, and Procedure. Int. J. Qual. Methods 2009, 8, 49-62. [CrossRef]

35. Miles, M.B.; Huberman, A.M. Qualitative Data Analysis: An Expanded Source Book, 2nd ed.; Sage: Newbury Park, CA, USA, 1994.

36. Hill, K. Landscape Architecture and Environmental Planning; Oxford University Press: Oxford, UK, 2018. [CrossRef]

37. McHarg, I.L. Design with Nature; Natural History Press: Garden City, NY, USA, 1969.

38. Swaffield, S.R. Theory in Landscape Architecture: A Reader; Penn Studies in Landscape Architecture; University of Pennsylvania Press: Philadelphia, PA, USA, 2002; ISBN 978-0-8122-1821-3.

39. Lélé, S.M. Sustainable Development: A Critical Review. World Dev. 1991, 19, 607-621. [CrossRef]

40. Sauvé, S.; Bernard, S.; Sloan, P. Environmental Sciences, Sustainable Development and Circular Economy: Alternative Concepts for Trans-Disciplinary Research. Environ. Dev. 2016, 17, 48-56. [CrossRef]

41. Carter, J.G.; Cavan, G.; Connelly, A.; Guy, S.; Handley, J.; Kazmierczak, A. Climate Change and the City: Building Capacity for Urban Adaptation. Prog. Plan. 2015, 95, 1-66. [CrossRef]

42. Rondinelli, D.A. Public Planning and Political Strategy. Long Range Plan. 1976, 9, 75-82. [CrossRef] 
43. Tyler, S.; Moench, M. A Framework for Urban Climate Resilience. Clim. Dev. 2012, 4, 311-326. [CrossRef]

44. Chaffin, B.C.; Gosnell, H.; Cosens, B.A. A Decade of Adaptive Governance Scholarship: Synthesis and Future Directions. E S 2014, 19, art56. [CrossRef]

45. Fankhauser, S.; Smith, J.B.; Tol, R.S.J. Weathering Climate Change: Some Simple Rules to Guide Adaptation Decisions. Ecol. Econ. 1999, 30, 67-78. [CrossRef]

46. Birchall, S.J.; MacDonald, S.; Slater, T. Anticipatory Planning: Finding Balance in Climate Change Adaptation Governance. Urban Clim. 2021, 37, 100859. [CrossRef]

47. Hill, K. Climate Change: Implications for the Assumptions, Goals and Methods of Urban Environmental Planning. UP 2016, 1, 103-113. [CrossRef]

48. Lawrence, J.; Bell, R.; Blackett, P.; Stephens, S.; Allan, S. National Guidance for Adapting to Coastal Hazards and Sea-Level Rise: Anticipating Change, When and How to Change Pathway. Environ. Sci. Policy 2018, 82, 100-107. [CrossRef]

49. Hannah, L. A Global Conservation System for Climate-Change Adaptation. Conserv. Biol. 2010, 24, 70-77. [CrossRef] [PubMed]

50. Wilder, M.; Scott, C.A.; Pablos, N.P.; Varady, R.G.; Garfin, G.M.; McEvoy, J. Adapting Across Boundaries: Climate Change, Social Learning, and Resilience in the U.S.-Mexico Border Region. Ann. Assoc. Am. Geogr. 2010, 100, 917-928. [CrossRef]

51. Graedel, T.E.; Allenby, B.R. Industrial Ecology and Sustainable Engineering; Prentice Hall: Upper Saddle River, NJ, USA, 2010; ISBN 978-0-13-600806-4.

52. Céspedes Restrepo, J.D.; Morales-Pinzón, T. Urban Metabolism and Sustainability: Precedents, Genesis and Research Perspectives Resour. Conserv. Recycl. 2018, 131, 216-224. [CrossRef]

53. Ioppolo, G.; Heijungs, R.; Cucurachi, S.; Salomone, R.; Kleijn, R. Urban metabolism: Many open questions for future answers. In Pathways to Environmental Sustainability: Methodologies and Experiences; Springer: Cham, Switzerland, 2013; p. 23. [CrossRef]

54. Jianguo, W. Urban Ecology and Sustainability: The State-of-the-Science and Future Directions: Actionable Urban Ecology in China and the World: Integrating Ecology and Planning for Sustainable Cities. Landsc. Urban Plan. 2014, 125, 209.

55. Kennedy, C.; Pincetl, S.; Bunje, P. The Study of Urban Metabolism and Its Applications to Urban Planning and Design. Environ. Pollut. 2011, 159, 1965-1973. [CrossRef]

56. Tarr, J.A. The Search for the Ultimate Sink. [Electronic Resource]: Urban Pollution in Historical Perspective; Technology and the Environment; University of Akron Press: Akron, OH, USA, 1996; Project MUSE: Baltimore, MD, USA, 2015; ISBN 978-1-935603-38-2.

57. Basiago, A.D. Economic, Social, and Environmental Sustainability in Development Theory and Urban Plan-Ning Practice: The Environmentalist; Kluwer Academic Publishers: Boston, MA, USA, 1999.

58. Berkes, F.; Colding, J.; Folke, C. (Eds.) Navigating Social-Ecological Systems: Building Resilience for Complexity and Change; Cambridge University Press: Cambridge, UK, 2003.

59. Baccini, P.; Brunner, P.H. Metabolism of the Anthroposphere: Analysis, Evaluation, Design; MIT Press: Cambridge, MA, USA, 2012; ISBN 978-0-262-30132-9.

60. Dipierri, A.A.; Zikos, D. The Role of Common-Pool Resources' Institutional Robustness in a Collective Action Dilemma under Environmental Variations. Sustainability 2020, 12, 10526. [CrossRef]

61. Stoddart, H.; Schneeberger, K.; Dodds, F.; Shaw, A.; Bottero, M.; Cornforth, J.; White, R. A Pocket Guide to Sustainable Development Governance; Commonwealth Secretariat; Stakeholder Forum: London, UK, 2011.

62. Gopalakrishnan, V.; Bakshi, B.R. Including nature in engineering decisions for sustainability. In Encyclopedia of Sustainable Technologies; Elsevier: Amsterdam, The Netherlands, 2017; pp. 107-116, ISBN 978-0-12-804792-7.

63. Lemons, J.; Westra, L.; Goodland, R. (Eds.) Ecological Sustainability and Integrity: Concepts and Approaches; Environmental Science and Technology Library; Springer: Dordrecht, The Netherlands, 1998; Volume 13, ISBN 978-90-481-4980-3.

64. Wheeler, S.M. Planning for Sustainability: Creating Livable, Equitable, and Ecological Communities; Routledge: London, UK, 2004; p. 289.

65. Young, O.R.; Berkhout, F.; Gallopin, G.C.; Janssen, M.A.; Ostrom, E.; van der Leeuw, S. The Globalization of Socio-Ecological Systems: An Agenda for Scientific Research. Glob. Environ. Chang. 2006, 16, 304-316. [CrossRef]

66. Neil Adger, W.; Arnell, N.W.; Tompkins, E.L. Successful Adaptation to Climate Change across Scales. Glob. Environ. Chang. 2005, 15, 77-86. [CrossRef]

67. Fischer, A.P. Pathways of Adaptation to External Stressors in Coastal Natural-Resource-Dependent Communities: Implications for Climate Change. World Dev. 2018, 108, 235-248. [CrossRef]

68. Smit, B.; Wandel, J. Adaptation, Adaptive Capacity and Vulnerability. Glob. Environ. Chang. 2006, 16, 282-292. [CrossRef]

69. Wilson, G.A. Community Resilience, Globalization, and Transitional Pathways of Decision-Making. Geoforum 2012, 43, 1218-1231. [CrossRef]

70. Fazey, I.; Wise, R.M.; Lyon, C.; Câmpeanu, C.; Moug, P.; Davies, T.E. Past and Future Adaptation Pathways. Clim. Dev. 2016, 8, 26-44. [CrossRef]

71. Pelling, M.; O’Brien, K.; Matyas, D. Adaptation and Transformation. Clim. Chang. 2015, 133, 113-127. [CrossRef]

72. Eisenhauer, D.C. Climate change; Adaptation. In International Encyclopedia of Human Geography; Elsevier: Amsterdam, The Netherlands, 2020; pp. 281-291, ISBN 978-0-08-102296-2.

73. Oberlack, C. Diagnosing Institutional Barriers and Opportunities for Adaptation to Climate Change. Mitig. Adapt. Strateg. Glob. Chang. 2017, 22, 805-838. [CrossRef] 
74. Scott, C.A.; Shrestha, P.P.; Lutz-Ley, A.N. The Re-Adaptation Challenge: Limits and Opportunities of Existing Infrastructure and Institutions in Adaptive Water Governance. Curr. Opin. Environ. Sustain. 2020, 44, 104-112. [CrossRef]

75. Kondo, T.; Lizarralde, G. Maladaptation, Fragmentation, and Other Secondary Effects of Centralized Post-Disaster Urban Planning: The Case of the 2011 “Cascading” Disaster in Japan. Int. J. Disaster Risk Reduct. 2021, 58, 102219. [CrossRef]

76. Gallopín, G.C. Linkages between Vulnerability, Resilience, and Adaptive Capacity. Glob. Environ. Chang. 2006, 16, 293-303. [CrossRef]

77. Eakin, H.C.; Lemos, M.C.; Nelson, D.R. Differentiating Capacities as a Means to Sustainable Climate Change Adaptation. Glob. Environ. Chang. 2014, 27, 1-8. [CrossRef]

78. Mccarthy, J.; Canziani, O.; Leary, N.; Dokken, D.; White, K. Climate Change 2001: Impacts, Adaptation, and Vulnerability. Contribution of Working Group II to the Fourth Assessment Report of the Intergovernmental Panel on Climate Change; Cambridge University Press: Cambridge, UK, 2001; Volume 19.

79. Adger, W.N. Vulnerability. Glob. Environ. Chang. 2006, 16, 268-281. [CrossRef]

80. Revi, A.; Satterthwaite, D.; Aragón-Durand, F.; Corfee-Morlot, J.; Kiunsi, R.B.R.; Pelling, M.; Roberts, D.; Solecki, W.; Gajjar, S.P.; Sverdlik, A. Towards Transformative Adaptation in Cities: The IPCC's Fifth Assessment. Environ. Urban. 2014, 26, 11-28. [CrossRef]

81. Oliver-Smith, A. Anthropological research on hazards and disasters. Annu. Rev. Anthropol. 1996, 25, 303-328. [CrossRef]

82. Alexander, D.E. Natural Disasters; Kluwer Academic Publishers: Boston, MA, USA, 1993.

83. Pescaroli, G.; Alexander, D. Understanding Compound, Interconnected, Interacting, and Cascading Risks: A Holistic Framework: A Holistic Framework for Understanding Complex Risks. Risk Anal. 2018, 38, 2245-2257. [CrossRef]

84. Dow, K.; Berkhout, F.; Preston, B.L.; Klein, R.J.T.; Midgley, G.; Shaw, M.R. Limits to Adaptation. Nat. Clim. Chang. 2013, 3, 305-307. [CrossRef]

85. Mack, R. Planning on Uncertainty: Decision Making in Business and Government Administration; Wiley Interscience: New York, NY, USA, 1971.

86. Haimes, Y.Y. Risk Modeling, Assessment, and Management; Wiley: Hoboken, NJ, USA, 2004.

87. Abbott, J. Understanding and Managing the Unknown: The Nature of Uncertainty in Planning. J. Plan. Educ. Res. 2005, 24, 237-251. [CrossRef]

88. Van Der Heijden, K. Scenarios: The Art of Strategic Conversation; John Wiley: Chichester, UK, 1996.

89. Martins, A.N.; Fayazi, M.; Kikano, F.; Hobeica, L. Enhancing Disaster Preparedness: From Humanitarian Architecture to Community Resilience, 1st ed.; Elsevier: Amsterdam, The Netherlands, 2020.

90. Holling, C.S. Resilience and Stability of Ecological Systems. Annu. Rev. Ecol. Syst. 1973, 4, 1-23. [CrossRef]

91. Rose, A. Economic Resilience to Natural and Man-Made Disasters: Multidisciplinary Origins and Contextual Dimensions. Environ. Hazards 2007, 7, 383-398. [CrossRef]

92. Twigg, J. Characteristics of a Disaster-Resilient Community: A Guidance Note; DFID DRR Interagency Coordination Group: London, UK, 2007.

93. UNISDR. How to Make Cities More Resilient: A Handbook for Local Government Leaders; United Nations: Geneva, Switzerland, 2012.

94. UNISDR. Sendai Framework for Disaster Risk Reduction; UNISDR: Geneva, Switzerland, 2015.

95. Holling, C.S.; Meffe, G.K. Command and Control and the Pathology of Natural Resource Management. Conserv. Biol. 1996, 10, 328-337. [CrossRef]

96. Lipshitz, R.; Strauss, O. Coping with Uncertainty: A Naturalistic Decision-Making Analysis. Organ. Behav. Hum. Decis. Process. 1997, 69, 149-163. [CrossRef]

97. Chow, C.C.; Sarin, R.K. Known, Unknown, and Unknowable Uncertainties. Theory Decis. 2002, 52, 127-138. [CrossRef]

98. Van der Heijden, J. Studying Urban Climate Governance: Where to Begin, What to Look for, and How to Make a Meaningful Contribution to Scholarship and Practice. Earth Syst. Gov. 2019, 1, 100005. [CrossRef]

99. Rauws, W. Embracing Uncertainty Without Abandoning Planning: Exploring an Adaptive Planning Approach for Guiding Urban Transformations. disP Plan. Rev. 2017, 53, 32-45. [CrossRef]

100. Fred, E.; Trist, E. The Causal Texture of Organisational Environments. Hum. Relat. 1965, 18, 21-32.

101. Christensen, K.S. Coping with Uncertainty in Planning. J. Am. Plan. Assoc. 1985, 51, 63-73. [CrossRef]

102. Fischhoff, B.; Davis, A.L. Communicating Scientific Uncertainty. Proc. Natl. Acad. Sci. USA 2014, 111, 13664-13671. [CrossRef] [PubMed]

103. Van der Bles, A.M.; van der Linden, S.; Freeman, A.L.J.; Mitchell, J.; Galvao, A.B.; Zaval, L.; Spiegelhalter, D.J. Communicating Uncertainty about Facts, Numbers and Science. R. Soc. Open Sci. 2019, 6, 181870. [CrossRef]

104. Shackle, G.L.S. Decision Order and Time in Human Affairs; Cambridge University Press: Cambridge, UK, 1969.

105. Gruber, J. Coordinating Growth Management through Consensus-Building: Incentives and the Generation of Social, Intellectual, and Political Capital; Institute of Urban and Regional Development (IURD), University of California, Berkeley: Berkeley, CA, USA, 1994.

106. Oppenheimer, M.; O’Neill, B.C.; Webster, M. Negative Learning. Clim. Chang. 2008, 89, 155-172. [CrossRef]

107. McInerney, D.; Lempert, R.; Keller, K. What Are Robust Strategies in the Face of Uncertain Climate Threshold Responses?: Robust Climate Strategies. Clim. Chang. 2012, 112, 547-568. [CrossRef] 
108. Reeder, T.; Ranger, N. How Do You Adapt in an Uncertain World? Lessons from the Thames Estuary 2100 Project; World Resources Report: Washington, DC, USA, 2010; p. 16.

109. Milly, P.C.D.; Betancourt, J.; Falkenmark, M.; Hirsch, R.M.; Kundzewicz, Z.W.; Lettenmaier, D.P.; Stouffer, R.J. Stationarity Is Dead: Whither Water Management? Science 2008, 319, 573-574. [CrossRef]

110. Stedinger, J.R.; Griffis, V.W. Getting From Here to Where? Flood Frequency Analysis and Climate1: Getting From Here to Where? Flood Frequency Analysis and Climate. JAWRA J. Am. Water Resour. Assoc. 2011, 47, 506-513. [CrossRef]

111. Stroup, L.J. Adaptation of U.S. Water Management to Climate and Environmental Change. Prof. Geogr. 2011, 63, 414-428. [CrossRef]

112. Cartwright, T.J. Problems, Solutions and Strategies: A Contribution to the Theory and Practice of Planning. J. Am. Inst. Plan. 1973, 39, 179-187. [CrossRef]

113. Pierre, N.J. Models of Urban Governance: The Institutional Dimension of Urban Politics. Urban Aff. Rev. 1999, 34, 372-396. [CrossRef]

114. Healey, P. Planning: Shaping Places in Fragmented Societies; Macmillan: Bassingstoke, UK, 1998.

115. Alexander, E. Dilemmas in Evaluating Planning, or Back to Basics: What Is Planning For? Plan. Theory Pract. 2009, 10, 233-244. [CrossRef]

116. Morphet, J. Effective Practice in Spatial Planning; The RTPI Library Series; Routledge: New York, NY, USA, 2011; ISBN 978-0-41549281-2.

117. Reyes Plata, J.A. Urban planning, urban design, and the creation of public goods. In Sustainable Cities and Communities; Leal Filho, W., Marisa Azul, A., Brandli, L., Gökçin Özuyar, P., Wall, T., Eds.; Encyclopedia of the UN Sustainable Development Goals; Springer International Publishing: Cham, Switzerland, 2020; pp. 899-905, ISBN 978-3-319-95716-6.

118. Bolan, R.S. Emerging Views of Planning. J. Am. Inst. Plan. 1967, 33, 233-245. [CrossRef]

119. Faludi, A. The Performance of Spatial Planning. Plan. Pract. Res. 2000, 15, 299-318. [CrossRef]

120. Forester, J. Critical Theory and Planning Practice. J. Am. Plan. Assoc. 1980, 46, 275-286. [CrossRef]

121. Kunzmann, K. Strategic spatial development through information and communication. In The Revival of Strategic Spatial Planning; Salet, W., Faludi, A., Eds.; Royal Netherlands Academy of Arts and Sciences: Amsterdam, The Netherlands, 2000 ; pp. $259-265$.

122. Rodima-Taylor, D.; Olwig, M.F.; Chhetri, N. Adaptation as Innovation, Innovation as Adaptation: An Institutional Approach to Climate Change. Appl. Geogr. 2012, 33, 107-111. [CrossRef]

123. Eriksen, S.; Brown, K. Sustainable Adaptation to Climate Change. Clim. Dev. 2011, 3, 3e6. [CrossRef]

124. Ribot, J.C. Vulnerability does not aall from the sky: Toward multi-scale propoor climate policy. In Social Dimensions of Climate Change: Equity and Vulnerability in a Warming World; Mearns, R., Norton, A., Eds.; The World Bank: Washington, DC, USA, 2010; pp. 47-74.

125. Pelling, M. Adaptation to Climate Change: From Resilience to Transformation; Routledge: London, UK, 2011.

126. Dowell, M.; Kitsuse, A. Constructing the Future in Planning: A Survey of Theories and Tools. J. Plan. Educ. Res. 2000, 19, $221-231$.

127. Leach, W.; Sabatier, P. Facilitators, coordinators, and outcomes. In The Promise and Performance of Environmental Conflict Resolution; O'Leary, R., Bingham, L.B., Eds.; Resources for the Future: Washington, DC, USA, 2003; pp. 148-171.

128. Ostrom, E. Governing the Commons: The Evolution of Institutions for Collective Action; Cambridge University Press: Cambridge, MA, USA, 1990

129. Roberts, N. Public Deliberation: An Alternative Approach to Crafting Policy and Setting Direction. Public Admin. Rev. 1997, 57, 124-132. [CrossRef]

130. Roberts, N. Keeping Public Officials Accountable through Dialogue: Resolving the Accountability Paradox. Public Admin. Rev. 2002, 62, 658-669. [CrossRef]

131. Ryan, C.M. Leadership in Collaborative Policy Making: An Analysis of Agency Roles in Regulatory Negotiation. Policy Sci. 2001, 34, 221-245. [CrossRef]

132. Moore, C.W. The Mediation Process: Practical Strategies for Resolving Conflict; Jossey-Bass: San Francisco, CA, USA, 1987.

133. Innes, J.E. Consensus Building: Clarifications for the Critics. Plan. Theory 2004, 3, 5-20. [CrossRef]

134. Susskind, L.; McKearnan, S.; Thomas-Larmer, J. (Eds.) The Consensus Building Handbook: A Comprehensive Guide to Reaching Agreement; Sage: Thousand Oaks, CA, USA, 1999.

135. Macintosh, A. Coastal Climate Hazards and Urban Planning: How Planning Responses Can Lead to Maladaptation. Mitig. Adapt. Strateg. Glob. Chang. 2013, 18, 1035-1055. [CrossRef]

136. Bulkeley, H.; Betsill, M.M. Revisiting the Urban Politics of Climate Change. Environ. Polit. 2013, 22, 136-154. [CrossRef]

137. Peterson, G.D.; Cumming, G.S.; Carpenter, S.R. Scenario Planning: A Tool for Conservation in an Uncertain World. Conserv. Biol. 2003, 17, 358-366. [CrossRef]

138. Albrechts, L. Bridge the Gap: From Spatial Planning to Strategic Projects. Eur. Plan. Stud. 2006, 14, 1487-1500. [CrossRef]

139. Soden, R.; Kauffman, N. Infrastructuring the imaginary: How sea-level rise comes to matter in the San Francisco Bay Area. In Proceedings of the 2019 CHI Conference on Human Factors in Computing Systems, Glasgow, UK, 4-9 May 2019; ACM: Glasgow, UK, 2019; pp. 1-11.

140. Balducci, A.; Boelens, L.; Hillier, J.; Nyseth, T.; Wilkinson, C. Introduction: Strategic Spatial Planning in Uncertainty: Theory and Exploratory Practice. Town Plan. Rev. 2011, 82, 481-501. [CrossRef] 
141. Daddi, T.; Bleischwitz, R.; Todaro, N.M.; Gusmerotti, N.M.; De Giacomo, M.R. The Influence of Institutional Pressures on Climate Mitigation and Adaptation Strategies. J. Clean. Prod. 2020, 244, 118879. [CrossRef]

142. Hughes, S. A Meta-Analysis of Urban Climate Change Adaptation Planning in the U.S. Urban Clim. 2015, 14, 17-29. [CrossRef]

143. Nalau, J.; Torabi, E.; Edwards, N.; Howes, M.; Morgan, E. A Critical Exploration of Adaptation Heuristics. Clim. Risk Manag. 2021, 32, 100292. [CrossRef]

144. Corfee-Morlot, J.; Cochran, I.; Hallegatte, S.; Teasdale, P.-J. Multilevel Risk Governance and Urban Adaptation Policy. Clim. Chang. 2011, 104, 169-197. [CrossRef]

145. Turkelboom, F.; Leone, M.; Jacobs, S.; Kelemen, E.; García-Llorente, M.; Baró, F.; Termansen, M.; Barton, D.N.; Berry, P.; Stange, E.; et al. When We Cannot Have It All: Ecosystem Services Trade-Offs in the Context of Spatial Planning. Ecosyst. Serv. 2018, 29, 566-578. [CrossRef]

146. Walker, W.E.; Rahman, S.A.; Cave, J. Adaptive Policies, Policy Analysis, and Policy-Making. Eur. J. Oper. Res. 2001, 128, $282-289$. [CrossRef]

147. Allen, C.R.; Garmestani, A.S. (Eds.) Adaptive Management of Social-Ecological Systems; Springer: Dordrecht, The Netherlands, 2015; ISBN 978-94-017-9681-1.

148. Hall, P.A. Policy Paradigms, Social Learning, and the State: The Case of Economic Policymaking in Britain. Comp. Polit. 1993, 25, 275-296. [CrossRef]

149. Allen, C.R.; Fontaine, J.J.; Pope, K.L.; Garmestani, A.S. Adaptive Management for a Turbulent Future. J. Environ. Manag. 2011, 92, 1339-1345. [CrossRef] [PubMed]

150. Folke, C.; Hahn, T.; Olsson, P.; Norberg, J. Adaptive governance of social-ecological systems. Annu. Rev. Environ. Resour. 2005, 30, 441-473. [CrossRef]

151. Burley, J.G.; McAllister, R.R.J.; Collins, K.A.; Lovelock, C.E. Integration, Synthesis and Climate Change Adaptation: A Narrative Based on Coastal Wetlands at the Regional Scale. Reg. Environ. Chang. 2012, 12, 581-593. [CrossRef]

152. Tol, R.S.J.; Klein, R.J.T.; Nicholls, R.J. Towards Successful Adaptation to Sea-Level Rise along Europe's Coasts. J. Coast. Res. 2008, 242, 432-442. [CrossRef]

153. Klein, R.J.T.; Tol, R.S.J. Adaptation to Climate Change: Options and Technologies. An Overview Paper; Technical Paper FCCC/TP/1997/3; United Nations Framework Convention on Climate Change Secretariat: Bonn, Germany, 1997; 36p.

154. Urwin, K.; Jordan, A. Does Public Policy Support or Undermine Climate Change Adaptation? Exploring Policy Interplay across Different Scales of Governance. Glob. Environ. Chang. 2008, 18, 180-191. [CrossRef]

155. Sabatier, P.A. Top-down and Bottom-up Approaches to Implementation Research: A Critical Analysis and Suggested Synthesis. J. Public Policy 1986, 6, 21-48. [CrossRef]

156. Mitchell, R.B.; Clark, W.C.; Cash, D.W.; Dickson, N. (Eds.) Global Environmental Assessments: Information, Institutions, and Influence; MIT: Cambridge, UK, 2006.

157. Cash, D.W.; Clark, W.C.; Alcock, F.; Dickson, N.M.; Eckley, N.; Guston, D.H.; Jaeger, J.; Mitchell, R.B. Knowledge Systems for Sustainable Development. Proc. Natl. Acad. Sci. USA 2003, 100, 8086-8091. [CrossRef]

158. Schroeder, H.; Kobayashi, Y. Climate change governance: Responding to an existential crisis. In The Impacts of Climate Change; Elsevier: Amsterdam, The Netherlands, 2021; pp. 479-489, ISBN 978-0-12-822373-4.

159. Habermas, J. Between Facts and Norms: Contributions to a Discourse Theory of Law and Democracy; MIT: Cambridge, UK, 1998.

160. Huntjens, P.; Lebel, L.; Pahl-Wostl, C.; Camkin, J.; Schulze, R.; Kranz, N. Institutional Design Propositions for the Governance of Adaptation to Climate Change in the Water Sector. Glob. Environ. Chang. 2012, 22, 67-81. [CrossRef]

161. Torabi, E.; Dedekorkut-Howes, A.; Howes, M. Adapting or Maladapting: Building Resilience to Climate-Related Disasters in Coastal Cities. Cities 2018, 72, 295-309. [CrossRef]

162. Barrett, S. Local Level Climate Justice? Adaptation Finance and Vulnerability Reduction. Glob. Environ. Chang. 2013, 23, 1819-1829. [CrossRef]

163. Moser, S.C.; Ekstrom, J.A.; Kim, J.; Heitsch, S. Adaptation Finance Archetypes: Local Governments' Persistent Challenges of Funding Adaptation to Climate Change and Ways to Overcome Them. E S 2019, 24, art28. [CrossRef]

164. Geels, F.W. Technological Transitions as Evolutionary Reconfiguration Processes: A Multi-Level Perspective and a Case-Study. Res. Policy 2002, 31, 1257-1274. [CrossRef]

165. Van Assche, K.; Beunen, R.; Duineveld, M. Evolutionary Governance Theory; Springer Briefs in Economics; Springer International Publishing: Cham, Switzerland, 2014; ISBN 978-3-319-00983-4.

166. Kwakkel, J.; van Der Pas, J.W.G.M. Evaluation of Infrastructure Planning Approaches: An Analogy with Medicine. Futures 2011, 43, 934-946. [CrossRef]

167. Goodwin, P.; Wright, G. The Limits of Forecasting Methods in Anticipating Rare Events. Technol. Forecast. Soc. Chang. 2010, 77, 355-368. [CrossRef]

168. Ostrom, E. Doing institutional analysis digging deeper than markets and hierarchies. In Handbook of New Institutional Economics; Menard, C., Shirley, M.M., Eds.; Springer: Boston, MA, USA, 2005; pp. 819-848, ISBN 978-0-387-25092-2.

169. Chaffin, B.C.; Shuster, W.D.; Garmestani, A.S.; Furio, B.; Albro, S.L.; Gardiner, M.; Spring, M.; Green, O.O. A Tale of Two Rain Gardens: Barriers and Bridges to Adaptive Management of Urban Stormwater in Cleveland, Ohio. J. Environ. Manag. 2016, 183, 431-441. [CrossRef] [PubMed] 
170. Andersson, E.; Barthel, S.; Borgström, S.; Colding, J.; Elmqvist, T.; Folke, C.; Gren, Å. Reconnecting Cities to the Biosphere: Stewardship of Green Infrastructure and Urban Ecosystem Services. Ambio 2014, 43, 445. [CrossRef] [PubMed]

171. Storbjörk, S.; Hedrén, J. Institutional Capacity-Building for Targeting Sea-Level Rise in the Climate Adaptation of Swedish Coastal Zone Management. Lessons from Coastby. Ocean Coast. Manag. 2011, 54, 265-273. [CrossRef]

172. Allen, K.M. Community-Based Disaster Preparedness and Climate Adaptation: Local Capacity-Building in the Philippines: Community-Based Disaster Preparedness and Climate Adaptation. Disasters 2006, 30, 81-101. [CrossRef]

173. Albrechts, L. More of the Same Is Not Enough! How Could Strategic Spatial Planning Be Instrumental in Dealing with the Challenges Ahead? Environ. Plan. B 2010,37, 1115-1127. [CrossRef]

174. Leck, H. What Lies beneath: Understanding the Invisible Aspects of Municipal Climate Change Governance. Curr. Opin. Environ. Sustain. 2015, 13, 61-67. [CrossRef]

175. Main, K.L.; Mazereeuw, M.; Masoud, F.; Lu, J.; Barve, A.; Ojha, M.; Krishna, C. Climate action zones: A clustering methodology for resilient spatial planning in climate uncertainty. In Enhancing Disaster Preparedness; Elsevier: Amsterdam, The Netherlands, 2021; pp. 241-258, ISBN 978-0-12-819078-4.

176. Nalau, J.; Preston, B.L.; Maloney, M.C. Is Adaptation a Local Responsibility? Environ. Sci. Policy 2015, 48, 89-98. [CrossRef]

177. Vogel, B.; Henstra, D. Studying Local Climate Adaptation: A Heuristic Research Framework for Comparative Policy Analysis. Glob. Environ. Chang. 2015, 31, 110-120. [CrossRef]

178. Bicknell, J.; Dodman, D.; Satterthwaite, D. (Eds.) Conclusions: Local development and adaptation. In Adapting Cities to Climate Change: Understanding and Addressing the Development Challenges; Earthscan: London, UK, 2009; pp. 359-383.

179. Bierbaum, R.; Smith, J.B.; Lee, A.; Blair, M.; Carter, L.; Chapin, F.S.; Fleming, P.; Ruffo, S.; Stults, M.; McNeeley, S.; et al. A Comprehensive Review of Climate Adaptation in the United States: More than before, but Less than Needed. Mitig. Adapt. Strateg. Glob. Chang. 2013, 18, 361-406. [CrossRef]

180. Warsen, R.; Nederhand, J.; Klijn, E.H.; Grotenbreg, S.; Koppenjan, J. What Makes Public-Private Partnerships Work? Survey Research into the Outcomes and the Quality of Cooperation in PPPs. Public Manag. Rev. 2018, 20, 1165-1185. [CrossRef]

181. Guston, D.H. Boundary Organizations in Environmental Policy and Science: An Introduction. Sci. Technol. Hum. Values 2001, 26, 339-408. [CrossRef]

182. Leck, H.; Simon, D. Fostering Multiscalar Collaboration and Co-Operation for Effective Governance of Climate Change Adaptation. Urban Stud. 2013, 50, 1221-1238. [CrossRef]

183. Glasbergen, P. Setting the scene: The partnership paradign in the making. In Partnerships, Governance and Sustainable Development: Reflections on Theory and Practice; Glasbergen, P., Biermann, F., Mol, A., Eds.; Elgar Publishing: Cheltenham, UK, 2007 ; p. 314.

184. Agrawal, A. Local institutions and adaptation to climate change. In Social Dimensions of Climate Change: Equity and Vulnerability in the Warming World; Mearns, R., Norton, A., Eds.; The World Bank: Washington, DC, USA, 2010; pp. 173-198.

185. Harman, B.P.; Taylor, B.M.; Lane, M.B. Urban Partnerships and Climate Adaptation: Challenges and Opportunities. Curr. Opin. Environ. Sustain. 2015, 12, 74-79. [CrossRef]

186. Bauer, A.; Steurer, R. Innovation in Climate Adaptation Policy: Are Regional Partnerships Catalysts or Talking Shops? Environ. Polit. 2014, 23, 818-838. [CrossRef]

187. Buck, L.E.; Geisler, C.C.; Schelhas, J.; Wollenberg, E. Biological Diversity: Balancing Interests through Adaptive Collaborative Management; CRC Press: Boca Raton, FL, USA, 2001.

188. Walters, C.J. Adaptive Management of Renewable Resources; McGraw Hill: New York, NY, USA, 1986.

189. Williams, B.K. Adaptive Management of Natural Resourceseframework and Issues. J. Environ. Manag. 2011, 92, 1346-1353. [CrossRef] [PubMed]

190. Gunderson, L. Resilience, Flexibility and Adaptive Management-Antidotes for Spurious Certitude? Conserv. Ecol. 1999, 3, 7. [CrossRef]

191. Demuzere, M.; Orru, K.; Heidrich, O.; Olazabal, E.; Geneletti, D.; Orru, H.; Bhave, A.G.; Mittal, N.; Feliu, E.; Faehnle, M. Mitigating and Adapting to Climate Change: Multi-Functional and Multi-Scale Assessment of Green Urban Infrastructure. J. Environ. Manag. 2014, 146, 107-115. [CrossRef]

192. Dewey, J. The Quest for Certainty: A Study of the Relation of Knowledge and Action. J. Philos. 1929, $27,14-25$.

193. Walters, C.J.; Holling, C.S. Large-Scale Experimentation and Learning by Doing. Ecology 1990, 71, 2060-2068. [CrossRef]

194. Allan, C.; Curtis, A. Nipped in the Bud: Why Regional Scale Adaptive Management Is Not Blooming. Environ. Manag. 2005, 36, 414-425. [CrossRef]

195. Garmestani, A.S.; Allen, C.R.; Cabezas, H. Panarchy, Adaptive Management and Governance: Policy Options for Building Resilience. Nebraska Law Review. 2008, 87, 1036.

196. Lee, K.N. Appraising adaptive management. In Biological Diversity; CRC Press: Boca Raton, FL, USA, 2021 ; p. 22.

197. Buijs, A.E.; Mattijssen, T.J.; Van der Jagt, A.P.; Ambrose-Oji, B.; Andersson, E.; Elands, B.H.; Steen Møller, M. Active Citizenship for Urban Green Infrastructure: Fostering the Diversity and Dynamics of Citizen Contributions through Mosaic Governance. Curr. Opin. Environ. Sustain. 2016, 22, 1-6. [CrossRef]

198. Stringer, L.C.; Dougill, A.J.; Fraser, E.; Hubacek, K.; Prell, C.; Reed, M.S. Unpacking "Participation" in the Adaptive Management of Social-Ecological Systems: A Critical Review. E S 2006, 11, art39. [CrossRef]

199. Moser, S.C.; Ekstrom, J.A. A Framework to Diagnose Barriers to Climate Change Adaptation. Proc. Natl. Acad. Sci. USA 2010, 107, 22026-22031. [CrossRef] [PubMed] 
200. Füssel, H.-M.; Klein, R.J.T. Climate Change Vulnerability Assessments: An Evolution of Conceptual Thinking. Clim. Chang. 2006, 75, 301-329. [CrossRef]

201. Hardin, G. The Tragedy of the Commons. Science 1968, 162, 1243-1248. [CrossRef]

202. Anderies, J.M. Economic Development, Demographics, and Renewable Resources: A Dynamical Systems Approach. Environ. Dev. Econ. 2003, 8, 219-246. [CrossRef]

203. Andersson, D.; Bratsberg, S.; Ringsmuth, A.K.; de Wijn, A.S. Dynamics of Collective Action to Conserve a Large Common-Pool Resource. Sci. Rep. 2021, 11, 9208. [CrossRef] [PubMed]

204. Marshall, G.R. Transaction Costs, Collective Action and Adaptation in Managing Complex Social-Ecological Systems. Ecol. Econ. 2013, 88, 185-194. [CrossRef]

205. Obeng-Odoom, F. The Meaning, Prospects, and Future of the Commons: Revisiting the Legacies of Elinor Ostrom and Henry George: The Meaning, Prospects, and Future of the Commons. Am. J. Econ. Sociol. 2016, 75, 372-414. [CrossRef]

206. Hinkel, J.; Bisaro, A. A Review and Classification of Analytical Methods for Climate Change Adaptation: Analytical Methods for Climate Change Adaptation. Wiley Interdiscip. Rev. Clim. Chang. 2015, 6, 171-188. [CrossRef]

207. Roggero, M. Adapting Institutions: Exploring Climate Adaptation through Institutional Economics and Set Relations. Ecol. Econ. 2015, 118, 114-122. [CrossRef]

208. Roggero, M.; Bisaro, A.; Villamayor-Tomas, S. Institutions in the Climate Adaptation Literature: A Systematic Literature Review through the Lens of the Institutional Analysis and Development Framework. J. Inst. Econ. 2018, 14, 423-448. [CrossRef]

209. Eakin, H. Institutional Change, Climate Risk, and Rural Vulnerability: Cases from Central Mexico. World Dev. 2005, 33, 1923-1938. [CrossRef]

210. Adger, W.N.; Huq, S.; Brown, K.; Conway, D.; Hulme, M. Adaptation to Climate Change in the Developing World. Prog. Dev. Stud. 2003, 3, 179-195. [CrossRef]

211. Pelling, M.; High, C. Understanding Adaptation: What Can Social Capital Offer Assessments of Adaptive Capacity? Glob. Environ. Chang. 2005, 15, 308-319. [CrossRef]

212. Wamsler, C.; Brink, E. Interfacing Citizens' and Institutions' Practice and Responsibilities for Climate Change Adaptation. Urban Clim. 2014, 7, 64-91. [CrossRef]

213. Gunderson, L.; Holling, C.S. (Eds.) Panarchy: Understanding Transformations in Human and Natural Systems; Island Press: Chicago, IL, USA, 2002.

214. Ekstrom, J.A.; Moser, S.C. Identifying and Overcoming Barriers in Urban Climate Adaptation: Case Study Findings from the San Francisco Bay Area, California, USA. Urban Clim. 2014, 9, 54-74. [CrossRef]

215. Juhola, S.; Glaas, E.; Linnér, B.-O.; Neset, T.-S. Redefining Maladaptation. Environ. Sci. Policy 2016, 55, 135-140. [CrossRef]

216. Rosenzweig, C.; Solecki, W.D.; Hammer, S.A.; Mehrohtra, S. (Eds.) Climate Change and Cities First Assessment Report of the Urban Climate Change Research Network; Cambridge University Press: Cambridge, UK, 2011.

217. Mehrotra, S.; Natenzon, C.; Omojola, A.; Folorunsho, R.; Gilbride, J.; Rosenzweig, C. Framework for city climate risk assess. In Proceedings of the Fifth Urban Research Symposium, Marseille, France, 28-30 June 2009; World Bank: Washington, DC, USA, 2009.

218. Burton, I. Climate Change and the Adaptation Deficit. Earthscan Reader on Adaptation to Climate Change; Schipper, E.L.F., Burton, I., Eds.; Earthscan: Sterling, VA, USA, 2009; pp. 89-95.

219. Chen, C.; Doherty, M.; Coffee, J.; Wong, T.; Hellmann, J. Measuring the Adaptation Gap: A Framework for Evaluating Climate Hazards and Opportunities in Urban Areas. Environ. Sci. Policy 2016, 66, 403-419. [CrossRef]

220. United Nations Environment Programme. Adaptation Gap Report; UNEP DTU Partnership (UDP): Nairobi, Kenya, 2020.

221. Davoudi, S.; Mehmood, A.; Brooks, E. The London Climate Change Adaptation Strategy: Gap Analysis; Newcastle University: Newcastle, UK, 2011.

222. Ostrom, E. A Diagnostic Approach for Going beyond Panaceas. Proc. Natl. Acad. Sci. USA 2007, 104, 15181-15187. [CrossRef] [PubMed]

223. Adger, W.N.; Dessai, S.; Goulden, M.; Hulme, M.; Lorenzoni, I.; Nelson, D.R.; Naess, L.O.; Wolf, J.; Wreford, A. Are There Social Limits to Adaptation to Climate Change? Clim. Chang. 2009, 93, 335-354. [CrossRef]

224. Bisaro, A.; Roggero, M.; Villamayor-Tomas, S. Analysis: Institutional Analysis in Climate Change Adaptation Research: A Systematic Literature Review. Ecol. Econ. 2018, 151, 34-43. [CrossRef]

225. Barnett, J.; Evans, L.S.; Gross, C.; Kiem, A.S.; Kingsford, R.T.; Palutikof, J.P.; Pickering, C.M.; Smithers, S.G. From Barriers to Limits to Climate Change Adaptation: Path Dependency and the Speed of Change. E S 2015, 20, art5. [CrossRef]

226. Healey, P. Transforming Governance: Challenges of Institutional Adaptation and a New Politics of Space. Eur. Plan. Stud. 2006, 14, 299-319. [CrossRef]

227. Arthur, W.B. Increasing Returns and Path Dependence in the Economy; University of Michigan Press: Ann Arbor, MI, USA, 1994.

228. Pierson, P. Increasing Returns, Path Dependence, and the Study of Politics. Am. Polit. Sci. Rev. 2000, 94, 251-267. [CrossRef]

229. Tilly, C. Big Structures, Large Processes, Huge Comparisons; Russel Sage: New York, NY, USA, 1984.

230. Sanyal, B. Planning as Anticipation of Resistance. Plan. Theory 2005, 4, 225-245. [CrossRef]

231. Booth, P. Culture, Planning and Path Dependence: Some Reflections on the Problems of Comparison. Town Plan. Rev. 2011, 82, 13-28. [CrossRef] 
232. Klein, R.J.T.; Midgley, G.F.; Preston, B.L.; Alam, M.; Berkhout, F.G.H.; Dow, K.; Shaw, M.R. Adaptation opportunities, constraints, and limits. In Climate Change 2014: Impacts, Adaptation, and Vulnerability. Part A: Global and Sectoral Aspects. Contribution of Working Group II to the Fifth Assessment Report of the Intergovernmental Panel on Climate Change; Cambridge University Press: Cambridge, NY, USA, 2014; pp. 899-943.

233. Hagedorn, K. Particular Requirements for Institutional Analysis in Nature-Related Sectors. Eur. Rev. Agric. Econ. 2008, 35, 357-384. [CrossRef]

234. Paavola, J. Institutions and Environmental Governance: A Reconceptualization. Ecol. Econ. 2007, 63, 93-103. [CrossRef]

235. Vatn, A. Institutions and the Environment; Edward Elgar Publishing: Cheltenham, UK, 2006.

236. Crawford, S.E.S.; Ostrom, E. A Grammar of Institutions. Am. Polit. Sci. Rev. 1995, 89, 582-600. [CrossRef]

237. Schotter, A. The Economic Theory of Social Institutions; Cambridge University Press: Cambridge, UK, 2008.

238. Basili, M.; Franzini, M.; Vercelli, A. Environment, Inequality and Collective Action; Routledge: London, UK; New York, NY, USA, 2006; ISBN 978-0-415-34234-6.

239. Sorensen, A. Institutions and Urban Space: Land, Infrastructure, and Governance in the Production of Urban Property. Plan. Theory Pract. 2018, 19, 21-38. [CrossRef]

240. Young, O.R. Land Use, Environmental Change, and Sustainable Development. Environ. Chang. 2011, 5, 66-85.

241. Knight, J.; Douglass, N. Explaining Economic Change: The Interplay Be- Tween Cognition and Institutions. Leg. Theory 1977, 3, 211-226. [CrossRef]

242. Milkoreit, M. Imaginary Politics: Climate Change and Making the Future. Elem. Sci. Anthropocene 2017, 5, 62. [CrossRef]

243. Ekers, M.; Loftus, A. The Power of Water: Developing Dialogues between Foucault and Gramsci. Environ. Plan. D Soc. Space 2008, 26, 698-718.

244. Swyngedouw, E. The Antinomies of the Postpolitical City: In Search of a Democratic Politics of Environmental Production. Int. J. Urban Reg. Res. 2009, 33, 601-620. [CrossRef]

245. Chhetri, N.; Easterling, W.E.; Terando, A.; Mearns, L. Modeling Path Dependence in Agricultural Adaptation to Climate Variability and Change. Ann. Assoc. Am. Geogr. 2010, 100, 894-907. [CrossRef]

246. Gollier, C.; Treich, N. Decision-Making under Scientific Uncertainty: The Economics of the Precautionary Principle. J. Risk Uncertain. 2003, 27, 77-103. [CrossRef]

247. Lempert, R.J.; Collins, M.T. Managing the Risk of Uncertain Thresholds Responses: Comparison of Robust, Optimum, and Precautionary Approaches. Risk Anal. 2007, 27, 1009-1026. [PubMed]

248. Scott, W. Institutions and Organizations. Leadersh. Organ. Dev. J. 2003, 24, 469-470. [CrossRef]

249. Smets, M.; Morris, T.; Greenwood, R. From Practice to Field: A Multilevel Model of Practice-Driven Institutional Change. AMJ 2012, 55, 877-904. [CrossRef]

250. Tilly, C. Mechanisms in Political Processes. Annu. Rev. Polit. Sci. 2001, 4, 21-41. [CrossRef]

251. Hodgson, G.M. What Are Institutions? J. Econ. Issues 2006, 40, 1-25. [CrossRef]

252. Agrawal, A. The Role of Local Institutions in Adaptation to Climate Change; The World Bank: Washington, DC, USA, 2008.

253. Mimura, N.; Pulwarty, R.S.; Duc, D.M.; Elshinnawy, I.; Redsteer, M.H.; Huang, H.Q.; Nkem, J.N.; Sanchez Rodriguez, R.A. Chapter 15: Adaptation planning and implementation. In Climate Change 2014: Impacts, Adaptation, and Vulnerability. Part A: Global and Sectoral Aspects. Contribution of Working Group II to the Fifth Assessment Report of the Intergovernmental Panel on Climate Change; Field, C.B., Barros, V.R., Dokken, D.J., Mach, K.J., Mastrandrea, M.D., Bilir, T.E., Chatterjee, M., Ebi, K.L., Estrada, Y.O., Genova, R.C., et al., Eds.; Cambridge University Press: Cambridge, UK; New York, NY, USA, 2014.

254. Keskitalo, E.C.H. (Ed.) Developing Adaptation Policy and Practice in Europe: Multi-Level Governance of Climate Change; Springer: Dordrecht, The Netherlands, 2010; ISBN 978-90-481-9324-0.

255. Bazerman, M. Climate Change as a Predictable Surprise. Clim. Chang. 2005, 77, 179-193. [CrossRef]

256. Biesbroek, G.R.; Termeer, C.J.A.M.; Kabat, P.; Klostermann, J.E.M. Institutional covernance barriers for the development and implementation of climate adaptation strategies. In Proceedings of the International Human Dimensions Programme (IHDP) Conference 'Earth System Governance: People, Places, and the Planet', Amsterdam, The Netherlands, 2-4 December 2009.

257. Hodgson, G.M.; Knudsen, T. Why We Need a Generalized Darwinism, and Why Generalized Darwinism Is Not Enough. J. Econ. Behav. Organ. 2006, 61, 1-19. [CrossRef]

258. MacKinnon, D.; Cumbers, A.; Pike, A.; Birch, K.; McMaster, R. Evolution in Economic Geography: Institutions, Political Economy, and Adaptation. Econ. Geogr. 2009, 85, 129-150. [CrossRef]

259. Koppel, B.M. (Ed.) Induced innovation theory, agricultural research, and Asia's green revolution: A reappraisal. In Induced Innovation Theory and International Agricultural Development: A Reassessment; John Hopkins University Press: Baltimore, MD, USA, 1995; pp. 56-72.

260. Petersen-Rockney, M.; Baur, P.; Guzman, A.; Bender, S.F.; Calo, A.; Castillo, F.; De Master, K.; Dumont, A.; Esquivel, K.; Kremen, C.; et al. Narrow and Brittle or Broad and Nimble? Comparing Adaptive Capacity in Simplifying and Diversifying Farming Systems. Front. Sustain. Food Syst. 2021, 5, 564900. [CrossRef]

261. Voigt, S. How (Not) to Measure Institutions. J. Inst. Econ. 2013, 9, 1-26. [CrossRef]

262. Lubell, M.; Robins, G.; Wang, P. Network Structure and Institutional Complexity in an Ecology of Water Management Games. E $S$ 2014, 19, art23. [CrossRef]

263. Armitage, D. Governance and the Commons in a Multi-Level World. Int. J. Commons 2008, 2, 7-32. [CrossRef] 
264. Huitema, D.; Adger, W.N.; Berkhout, F.; Massey, E.; Mazmanian, D.; Munaretto, S.; Plummer, R.; Termeer, C.C.J.A.M. The Governance of Adaptation: Choices, Reasons, and Effects. Introduction to the Special Feature. E S 2016, 21, art37. [CrossRef]

265. Berkes, F. Indigenous Ways of Knowing and the Study of Environmental Change. J. R. Soc. N. Z. 2009, 39, 151-156. [CrossRef]

266. Naess, L.O. The Role of Local Knowledge in Adaptation to Climate Change: Role of Local Knowledge in Adaptation. WIREs Clim. Chang. 2013, 4, 99-106. [CrossRef]

267. Dovers, S.R.; Hezri, A.A. Institutions and Policy Processes: The Means to the Ends of Adaptation. WIREs Clim. Chang. 2010, 1, 212-231. [CrossRef]

268. Ostrom, E. Nested Externalities and Polycentric Institutions: Must We Wait for Global Solutions to Climate Change before Taking Actions at Other Scales? Econ. Theory 2012, 49, 353-369. [CrossRef]

269. Bromley, D.W. Searching for Sustainability: The Poverty of Spontaneous Order. Ecol. Econ. 1998, 24, 231-240. [CrossRef]

270. Van Klingeren, F.; de Graaf, N.D. Heterogeneity, Trust and Common-Pool Resource Management. J. Environ. Stud. Sci. 2021, 11, 37-64. [CrossRef]

271. Wilson, J. Scientific Uncertainty, Complex Systems, and the Design of Common-Pool Institutions; National Resource Council: Washington, DC, USA, 2002; p. 24.

272. Gardiner, S.M. A Perfect Moral Storm: Climate Change, Intergenerational Ethics and the Problem of Moral Corruption. Environ. Values 2006, 15, 397-413. [CrossRef]

273. Greif, A.; Kingston, C. Institutions: Rules or equilibria? In Political Economy of Institutions, Democracy and Voting; Schofield, N., Caballero, G., Eds.; Springer: Berlin/Heidelberg, Germany, 2011; pp. 13-43, ISBN 978-3-642-19518-1. 